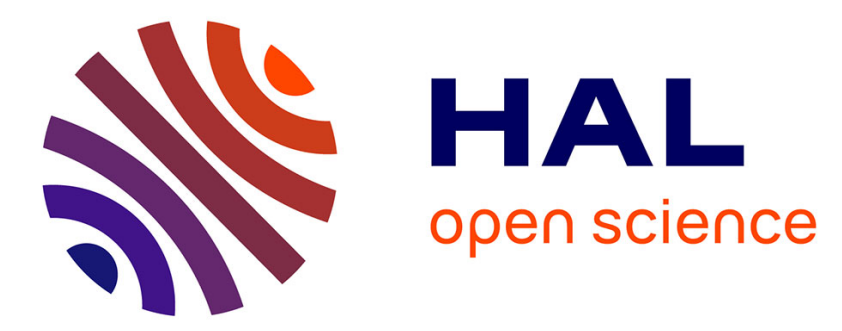

\title{
Granite intrusion in a metamorphic core complex: The example of the Mykonos laccolith (Cyclades, Greece)
} Yoann Denèle, Emmanuel Lecomte, Laurent Jolivet, Olivier Lacombe, Loic Labrousse, Benjamin Huet, Laetitia Le Pourhiet

\section{- To cite this version:}

Yoann Denèle, Emmanuel Lecomte, Laurent Jolivet, Olivier Lacombe, Loic Labrousse, et al.. Granite intrusion in a metamorphic core complex: The example of the Mykonos laccolith (Cyclades, Greece).

Tectonophysics, 2011, 501 (1-4), pp.52-70. 10.1016/j.tecto.2011.01.013 . insu-00563983

\section{HAL Id: insu-00563983 \\ https://hal-insu.archives-ouvertes.fr/insu-00563983}

Submitted on 7 Apr 2011

HAL is a multi-disciplinary open access archive for the deposit and dissemination of scientific research documents, whether they are published or not. The documents may come from teaching and research institutions in France or abroad, or from public or private research centers.
L'archive ouverte pluridisciplinaire HAL, est destinée au dépôt et à la diffusion de documents scientifiques de niveau recherche, publiés ou non, émanant des établissements d'enseignement et de recherche français ou étrangers, des laboratoires publics ou privés. 


\title{
Granite intrusion in a metamorphic core complex: The example of the Mykonos laccolith (Cyclades, Greece)
}

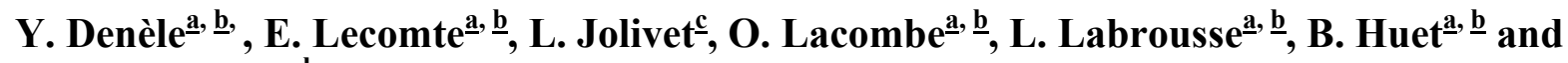 \\ L. Le Pourhiet ${ }^{-\underline{a}}$ \\ ${ }^{\mathrm{a}}$ UPMC Univ Paris 06, UMR 7193, ISTEP, F-75005, Paris, France \\ ${ }^{\mathrm{b}}$ CNRS, UMR 7193, ISTEP, F-75005, Paris, France

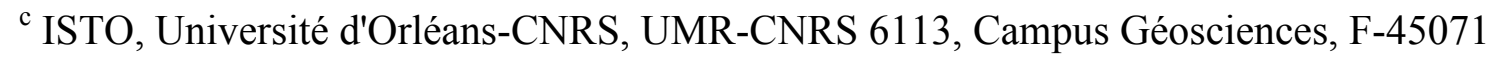 \\ Orléans, France
}

\begin{abstract}
The Aegean domain is a well-suited place to study the formation of metamorphic core complex (MCC) and to investigate the role of syn-tectonic granites on their development. In the northern Cyclades, the Mykonos-Delos-Rhenia MCC is characterized by the intrusion of a kilometer-scale Late Miocene pluton of I-type granitoids within a migmatitic gneiss dome. New combined AMS (anisotropy of magnetic susceptibility) and microstructural studies on the Mykonos granitoids together with recently published thermochronological data allow us to use the granitoids as strain markers.
\end{abstract}

The Mykonos granitoids form a laccolith-like intrusion with a $\mathrm{N} 70^{\circ} \mathrm{E}$ long axis. The laccolith is strongly asymmetric with an outlying root zone to the SW and a major body mainly developed to the NE. The laccolith construction is due to successive pulses of more or less differentiated magma that intruded the Cycladic Blueschist Unit. The attitude of stretching markers suggests an important (about $60^{\circ}$ ) vertical-axis local rotation phenomenon in the cycladic upper crust during the exhumation of the Mykonos MCC. Structural data suggest a four-stage evolution of the Mykonos MCC: (i) a first stage characterized by flat shearing toward the $\mathrm{N}-\mathrm{NE}$ and by the formation of a domal structure in migmatitic paragneisses with multi-scale generation of folds with axes either perpendicular or parallel to the regional stretching, as a result of the interplay between regional $\mathrm{N} 20^{\circ} \mathrm{E}$-directed extension and $\mathrm{EW}$ shortening; (ii) a second stage marked by the emplacement of the Mykonos laccolith at $13.5 \pm 0.3 \mathrm{Ma}$ at the top of the migmatitic paragneisses; (iii) the third stage corresponding to the development of protomylonitic foliations and lineations in the whole laccolith in high to medium temperature conditions; and (iv) the late stage marked by an acceleration of the exhumation of the Mykonos MCC. This exhumation was accommodated by important rotations of upper crustal blocks. During the end of the exhumation processes, around $10 \mathrm{Ma}$, deformation localized at the top of the laccolith in semi-ductile conditions and then in brittle conditions in the major detachment plane.

Our study shows that the Cycladic plutonism event had no role on the initiation of the MCC. However, the geometry of the Mykonos intrusion supports that the magmas are "sucked" into the direction of regional extension and that the intrusion of magmas has caused an acceleration of the last stages of the MCC development. This acceleration was marked by a very fast exhumation of the laccolith after its emplacement. 
Keywords: Aegean domain; Mykonos island; Metamorphic core complex; Syntectonic pluton; Block rotation; AMS

\section{Introduction}

Metamorphic core complexes (MCC) or extensional gneiss domes are crustal-scale structures that develop during extension of a thickened and thermally mature crust ([Coney and Harms, 1984], [Lister and Davis, 1989], [Malavieille, 1993] and [Whitney et al., 2004]). Their overall geometry is rather simple, with a shallow-dipping detachment separating an upper plate, without any significant metamorphism, from a lower plate, the gneiss dome, showing an evolution toward high-temperature metamorphic paragneisses in the amphibolite facies with frequent partial melting. The relationships between the detachment and the gneiss dome have been envisaged in various ways and have given rise to various models. Some models use a pre-existing fault in the brittle upper crust to develop a MCC ([Buck, 1993], [Koyi and Skelton, 2001], [Lavier et al., 1999] and [Rey et al., 2009]). In these models, the formation of the dome is a consequence of the displacement along the detachment. An alternative view is to consider the detachment not as the primary cause for the formation of the MCC but instead as a consequence. In this case, numerical and anologue modeling emphasize the importance of pre-existing viscosity-density anomalies such as a granite or a migmatitic body below the brittle-ductile transition ([Brun et al., 1994], [Tirel et al., 2004], [Tirel et al., 2008] and [Vanderhaeghe and Teyssier, 2001]).

Field studies of MCC show a spatial and temporal link between MCC formation and plutonic activity as documented for instance in those of the Basin and Range Province (see Crittenden et al., 1980, and references therein), the Canadian Cordillera (e.g. Vanderhaeghe et al., 1999), the Variscan belt (e.g. Vanderhaeghe et al., 1999) and the Mediterranean Region ([Daniel and Jolivet, 1995] and [Lister and Baldwin, 1993]). Numerous combined field and thermochronological studies suggest a «triggering effect» of granitic intrusion on the development of MCC as in the Basin and Range Province ([Foster et al., 2001] and [Lister and Baldwin, 1993]), in the D'Entrecasteaux islands in Papua New Guinea ([Baldwin et al., 1993] and [Lister and Baldwin, 1993]) and in the North Himalaya metamorphic domes (Aoya et al., 2005). In the Aegean domain, which is a natural laboratory for studying the coeval formation of MCC and emplacement of syn-tectonic granites (e.g. [Gautier et al., 1993] and [Jolivet et al., 2004]), Lister and Baldwin (1993) proposed that granite emplacement triggered continental extension. An opposite conclusion was however drawn by (Brichau et al., 2007) and (Brichau et al., 2008), who showed instead, based on thermochronological studies, that there is no link between granite intrusion and time-averaged displacement rates along the detachment, which implies that magmatism does not necessarily enhance continental extension.

In the northern Aegean domain, the Mykonos-Delos-Rhenia MCC is characterized by the intrusion of a kilometer-scale late Miocene pluton of I-type granitoids within a migmatitic gneiss dome ([Faure et al., 1991], [Lee and Lister, 1992] and [Lucas, 1999]). In this paper, we present a study of the evolution of the ductile deformation in a $2 \mathrm{~km}$-thick crustal crosssection within the granitoids and migmatites of the Mykonos MCC beneath the Nord Cycladic Detachment System (Jolivet et al., 2010). AMS (anisotropy of magnetic susceptibility) and microstructural studies in the granitoids combined with recent cooling rates obtained by Brichau et al. (2008) allow to use the granitoids as strain markers and then to discuss the role of granitic intrusions on the development of a MCC. Besides, rotations about vertical axis are 
an important ingredient of the tectonic history of the Aegean region ([Kissel and Laj, 1988] and [van Hinsbergen et al., 2005]) and Miocene granites do not escape such rotations as shown by paleomagnetic studies ([Avigad et al., 1998] and [Morris and Anderson, 1996]). The interplay between detachments and rotation is an important topic that can be discussed in the light of the Mykonos MCC.

\section{Geological setting}

The Cyclades form an archipelago in the center of the Aegean domain. Following an Eocene episode of crustal thickening, this domain underwent backarc extension since the Oligocene above the retreating Hellenic slab ([Jolivet and Faccenna, 2000], [Le Pichon and Angelier, 1980], [Lister et al., 1984], [Ring et al., 2001], [Vanderhaeghe and Teyssier, 2001] and [Vanderhaeghe et al., 2007]). The extensional stage was accompanied by the formation of several MCC and associated detachments ([Gautier and Brun, 1994], [Gautier et al., 1993], [Mehl et al., 2005] and [Mehl et al., 2007]) as well as by the intrusion of granitic plutons. The original nappe stack can still be recognized despite an intense reworking by extension ([Bonneau, 1984] and [Jolivet et al., 2004]); from top to base: (i) the Upper Cycladic Nappe, essentially made of ophiolitic material and devoid of any Tertiary metamorphic paragneisses constitutes the top of the stack; (ii) the Cycladic Blueschists (Blake et al., 1981) form the middle part of the stack and are constituted by metapelites, marbles and metabasites that have recorded a complex metamorphic evolution with Eocene high-pressure and low-temperature (HP-LT) paragneisses overprinted by Oligo-Micocene high-temperature and low-pressure (HT-LP) paragneisses ([Altherr et al., 1982], [Parra et al., 2002] and [Trotet et al., 2001]); and (iii) the Cycladic basement at the base of the stack; this basement unit was metamorphosed under amphibolite-facies associated with partial melting; this metamorphic evolution is mainly Oligo-Miocene in age with only scarce remnants of the Eocene HP-LT stage (e.g. Altherr et al., 1982). At the scale of the Aegean the transition from compressional to extensional tectonics corresponds to an acceleration of slab retreat some 30-35 Ma ago, as shown by the migration of the magmatic arc through time (Jolivet and Brun, 2010). The precise timing of the HP-LT and HT-LP stages is however still debated in the details. For Forster and Lister (2009) extension in the southern Cyclades (Ios island) began at $35 \mathrm{Ma}$, i.e. at the Eocene-Oligocene transition, whereas for Huet et al. (2009) it began slightly later, at approximately $30 \mathrm{Ma}$. These two contrasted views are due to a disagreement on the interpretation of south-verging shear bands in the south of Ios island, which are thought to have formed during extension by Forster and Lister (2009) but instead during the HP-LT shortening stage according to Huet et al. (2009).

Located in the Northern Cyclades (Fig. 1a), the Mykonos, Delos and Rhenia islands belong to the Mykonos MCC ([Faure et al., 1991] and [Lee and Lister, 1992]) formed in the footwall of the North Cycladic Detachment System (NCDS), one of the largest detachment of the Cyclades (Jolivet et al., 2010). The core of the MCC is made of a kilometer-scale laccolith (Fig. 1b) of I-type granitoids on Mykonos and Delos islands and by migmatitic paragneisses on Rhenia and Mykonos islands. The laccolith has a monzogranitic to granodioritic composition with an inverted zonation, i.e. more mafic toward the pluton center (Lucas, 1999). The roof of the laccolith is cut by the NCDS and its floor is made of migmatitic gneiss belonging to the Cycladic basement. Emplacement of the laccolith is dated at $13.5 \pm 0.3 \mathrm{Ma}$ using the U/Pb technique on zircon (Brichau et al., 2008). Various studies ([Faure et al., 1991], [Lecomte et al., 2010], [Lee and Lister, 1992] and [Lucas, 1999]) show that the pluton was affected by an intense mylonitic deformation at high temperature, which supports its syntectonic emplacement. 
(Avigad et al., 1998) and (Lee and Lister, 1992) showed that the Mykonos granitoids are topped by a low-angle normal fault system. Jolivet et al. (2010) demonstrated that this lowangle normal fault system belongs to the NCDS and Lecomte et al. (2010) showed that this system is subdivised into two branches in this area, the so-called Livada and Mykonos detachments. The Livada detachment corresponds to a low-angle ductile shear zone that reworked the intrusive contact of the granite within the metabasites of the upper plate. The Mykonos detachment is a cataclastic-brittle low-angle normal fault. The hanging wall of the detachment system is constituted by late Miocene continental sandstones and conglomerates (Sanchez-Gomez et al., 2002). Low-temperature thermochronology performed by Brichau et al. (2008) on the Mykonos granitoids allows dating of the activity of the Mykonos detachment between $\mathrm{ca} .14$ and $10 \mathrm{Ma}$. The detachment slipped at an average rate of $6.0+9.2 /-2.4 \mathrm{~km} / \mathrm{Ma}$ and caused $c a .30 \mathrm{~km}$ of offset between hangingwall and footwall (Brichau et al., 2008) and ca. $8 \mathrm{~km}$ of exhumation of the footwall (Lecomte et al., 2010). The Mykonos laccolith and the NCDS are cut by a recent N-S trending graben bounded by a major, west-dipping normal fault striking $\mathrm{N} 155^{\circ} \mathrm{E}$ and a minor, east dipping conjugate normal fault striking $\mathrm{N} 170^{\circ} \mathrm{E}$ (Faure et al., 1991), that likely connect close to Elia (Fig. 1b). Vertical displacement on the eastern normal fault in Panormos is estimated at $800 \mathrm{~m}$ while vertical displacement on the western normal fault remains lower.

\section{Petrostructural, microstructural and kinematic characteristics of the Mykonos laccolith}

Fabrics were measured both in the field and by using the AMS technique. This technique allows to define the orientation of the magnetic foliation and lineation and the magnetic susceptibility ellipsoid (considered as a proxy of the finite strain ellipsoid, see below). The principle of this technique is based on the measurements of the orientations and magnitudes of the three principal axes $K 1 \geq K 2 \geq K 3$ of the magnetic susceptibility ellipsoid. The AMS technique applied to granitic rocks has been the topic of several works ([Borradaile and Henry, 1997], [Borradaile and Jakson, 2010], [Bouchez, 1997] and [Bouchez, 2000]), so there is no need to enter into much detail hereinafter.

The AMS technique has been used to study 36 samples in the Mykonos granitoids (Table 1). At each site, two to five cylindrical cores were drilled, each of them being then cut into two ca. $10.8 \mathrm{~cm}^{3}$ samples. Each sample was separately measured at low field $\left(300 \mathrm{~A} \mathrm{~m}^{-1}, 875 \mathrm{~Hz}\right)$ on a Kappabridge KLY-3 susceptometer. All samples display Mean Susceptibility values $(\mathrm{Km})<282 \mu \mathrm{SI}$ (Table 1). Such low values are typical of a dominantly paramagnetic behavior, i.e. where the magnetic carriers are the iron-bearing silicates ([Borradaile and Jakson, 2010] and [Rochette et al., 1992]). In order to better characterize the magnetic behavior of our samples, we have performed measurements of the Mean Susceptibility versus temperature ( Km vs $T$ ) on 3 samples (Fig. 2). These samples show a purely paramagnetic behavior with a rather regular decrease of $\mathrm{Km}$ when $T$ increases. These measurements unambiguously demonstrate the purely paramagnetic behavior of the Mykonos granites.

In dominantly paramagnetic granites, several studies (e.g. [Gleizes et al., 2001], [Gleizes et al., 2006] and [Ono et al., 2009]) show that there is a good correlation between magnetic lineation (K1) and foliation (plane normal to K3) and mineral lineation and foliation, respectively. Moreover, in these granites $\mathrm{Km}$ is proportional to the iron content of the iron-bearing silicates and thus it can be directly correlated to the modal content in biotite, amphibole and pyroxene. Finally we have measured the magnetic anisotropy $(P p \%=100 \times[(K 1-D) /(K 3-D)-1])$ where $D$ is the diamagnetic contribution estimated at $-14 \mu \mathrm{SI}$ (Rochette, 1987), and the shape 
parameter $\left(T=\ln \left[K 2^{2} /(K 1 \times K 3)\right] / \ln [K 1 / K 3]\right)$ of Jelinek $(1981)$. In rocks dominated by paramagnetic carriers, several studies (e.g. [Denèle et al., 2008] and [Gleizes et al., 2001]) have shown that the value of $P p \%$ correlates well with the amount of deformation. In contrast, the behavior of the shape parameter $T$ is more complex since it depends on both the deformation regime and the amount of ferromagnesian minerals in the specimen (Gleizes et al., 2006).

\subsection{Petrography and relationships between the different petrographic types}

Mykonos island is formed mainly by plutonic rocks belonging to the Mykonos laccolith (Fig. 1b). Whereas the top of the laccolith has been reworked by the Livada detachment ([Jolivet et al., 2010] and [Lecomte et al., 2010]), the original intrusive contact can still be observed in Cape Evros sector where the granitoids intrude metabasic rocks belonging to the upper Cycladic unit (Fig. 3a). The major contact corresponds to a shallow-dipping plane, associated to sills and dikes swarms. The bottom of the laccolith can be observed in the sector of Appolonion where the granitoids intrude mainly paragneisses belonging to the Cycladic basement and more rarely micaschists. This contact is subhorizontal and diffuse with numerous enclaves of paragneisses and marbles in the granite (Fig. 1b).

Following optical microscopy examinations, four petrographic types were identified in the laccolith. From the more differentiated ones to the mafic ones (Fig. 1b), these types are: (1) a syenogranite identified only near Cape Evros sector in a $1 \mathrm{~km}$-wide band intrusive in metabasites belonging to the Upper Cycladic Unit; (2) a biotite monzogranite (or leucogranite) cropping out discontinuously at the contact with country rocks at the bottom of the laccolith in the Appolonion sector and which makes 10\% max. of the surface of the pluton; (3) a biotite hornblende porphyric monzogranite which constitutes the major part of the pluton; and (4) a pyroxene porphyric granodiorite with mafic bodies which represents $20 \%$ max. of the surface of the pluton. The values of $K m(\mu \mathrm{SI})$, ranging from 42 to 282 , can be correlated with the rock types as follows (Fig. 1c): syenogranite and biotite leucogranite $42<K m<100$, monzogranite $100<K m<190$, granodiorite $190<K m<282$. Such a wide range of susceptibilities reflects the diversity of the plutonic rocks in the Mykonos laccolith.

A subhorizontal layering of magmatic origin with alternations of biotite granite and pyroxene granodiorite can be observed close to the contact between these two lithologies on the Northwestern coast of Mykonos island (Fig. 3b). Enclaves of biotite granite in hornblende monzogranite and pyroxene granodiorite can locally be observed ([Fig. 1] and [Fig. 3]). The pyroxene granodiorite is rich in various enclaves of basic rocks such as gabbro, diorite, monzodiorite and monzonite constituted by $\mathrm{Pl}+\mathrm{Cpx}+\mathrm{Qz} \pm \mathrm{Afs} \pm \mathrm{Hbl}$ (see Whitney and Evans, 2010 for mineral abbreviations) generally concentrated in swarm complexes. Many enclaves of country-rocks are also observed, mainly at the bottom contact in the Appolonion sector but sometimes also in the center of the laccolith (Fig. 1b). Near Cape Evros the granites are cut by a network of subvertical barite veins striking $\sim \mathrm{N} 130^{\circ} \mathrm{E}$.

\subsection{Microstructure and AMS scalar parameters}

Deformation was studied on thin sections and through AMS measurements. As discussed below, the AMS scalar parameters can be used as tools for characterizing strain heterogeneity. However these parameters have to be independent of the petrography and so of the type of magnetic carrier. For the paramagnetic granites of Mykonos the $P p \%$ vs $\mathrm{Km}$ and $\mathrm{T}$ vs $\mathrm{Km}$ (Fig. 4) diagrams demonstrate this relative independence. 
The microstructural study underlines the presence of two domains of deformation (Fig. 4). The first domain is a narrow, max. $2 \mathrm{~km}$ wide, band close to the NCDS. It corresponds to an association of cataclasites and low-temperature mylonites and ultramylonites. The second domain of deformation is observed in the major part of the laccolith and corresponds to an association of high-temperature protomylonites and submagmatic microstructures.

The first domain of deformation can be studied in details in two sectors close to the NCDS: Panormos Bay and Cape Evros. At Panormos Bay, where the granite crops out directly under the Mykonos brittle detachment (Lecomte et al., 2010), this domain is characterized only by cataclasis marked in thin section by intensely fractured quartz and feldspar grains (Fig. 3c). The cataclasites do not present any significant structural anisotropy as shown by the very low values of Anisotropy Total parameter Pp\% (ca. 3\%). At Cape Evros where the ductile Livada detachment is preserved below the Mykonos brittle detachment and at the top of the laccolith, this domain of deformation shows an alternation of cataclasites, mainly close to the major plane of detachment, and of mylonite and ultramylonite bands. The mylonites and ultramylonites are characterized by (i) intense dynamic recrystallisation in quartz grains (dislocation creep regime 2 of Hirth and Tullis, 1992), (ii) intense fracturing of feldspars, (iii) replacement of biotite grains by chlorite, and (iv) a percentage of matrix higher than $60 \%$, which can reach $80 \%$ in ultramylonites (Fig. 3d). Intense fracturing of feldspars, secondary formation of chlorite and formation of cataclastic bands suggest a low temperature deformation regime. The mylonites and ultramylonites at Cape Evros are associated with rather high values of $P p \%$ ranging from 5 to $12 \%$. These values are lower than those predicted for these types of microstructures (e.g. Denèle et al., 2008). This observation can be explained by the very low values of Mean Susceptibility $(\mathrm{Km})$ of these samples which reflect a very low content of ferromagnesian mineral species.

The second domain of deformation is observed in the center and at the bottom of the laccolith. Protomylonites are characterized by slight dynamic recrystallisation in quartz grains (dislocation creep regime 2 of Hirth and Tullis, 1992), bending and limited fracturing of feldspars and by a percentage of recrystallized matrix lower than $30 \%$ (Fig. 3e). These microstructures were formed at high to moderate temperature in the solid state $\left(\mathrm{ca} .500^{\circ} \mathrm{C}\right)$ as attested by the presence of plagioclase grains undergoing bending (i.e. deformed at temperature higher than their plasticity threshold) and limited fracturing. Submagmatic microstructures are marked by sub-solidus fracturing of felsdpar phenocrysts. Near the bottom of the laccolith, mylonitic cm-thick bands can be observed locally (Fig. 4). These mylonites were also formed at high to moderate temperature conditions. Finally the western extremity of the Appolonion peninsula corresponds to a submagmatic domain devoid of any mylonitic or protomylonitic band (Fig. 4).

The fabric parameter $T$ shows an evolution from planar to strongly planar fabrics close to the detachment to planar-linear fabrics at the bottom of the laccolith (Fig. 4).

\subsection{Structures}

Measurements of the vectorial parameters of AMS show a good correlation with field observations (Table 1). We plotted our own measurements of foliations and associated stretching lineations and those of Lucas (1999) on Fig. 5.

In the Mykonos granite the foliation (Fig. 5a) shows a consistent $\mathrm{N}-\mathrm{S}$ trend and it dips gently to the east. At the map scale, foliation trajectories display an elliptic configuration elongated 
$\mathrm{N} 80^{\circ} \mathrm{E}$. In more details, foliation trajectories are concave toward Delos island which constitutes the central part of the elliptical structure. At map scale the foliation contours are concordant with the petrographic zonation. Along E-W cross-sections (Fig. 6) from top to bottom, the foliation dips very gently to the east close to the detachment, becomes steeper in the core of the laccolith $\left(20\right.$ to $\left.40^{\circ}\right)$ and dips gently to the west in the western edge of the island, especially in the sector of Appolonion.

At the outcrop scale, lineations are everywhere homogeneously oriented. However, at the scale of the Mykonos laccolith, the pattern of stretching lineations shows a curvature from a $33^{\circ} \mathrm{E}$ direction at Cape Evros, a $61^{\circ} \mathrm{E}$ direction at Kalafati Bay to a nearly E-W trend in the Appolonion peninsula (Fig. 5b). All these lineations are systematically associated with top-tothe-East/North-East sense of shear in the mylonitic sector close to the detachment but also in the mylonitic non-penetrative $\mathrm{cm}$-thick bands in the protomylonitic domain. These stretching lineations are systematically associated with fractures filled with greenschist-facies minerals: epidote + albite + chlorite + quartz. These late fractures are nearly vertical and strike perpendicular to the stretching lineations.

In the various enclaves of country rocks belonging to both the Cycladic Blueschists and the Cycladic basement, foliations and lineations are concordant with the mylonitic foliation of the granitoids.

\section{Structural characteristics of the migmatitic Rhenia-Delos dome and the root zone of the Mykonos laccolith}

Located $5 \mathrm{~km}$ to the west of Appolonion Peninsula (Fig. 1b), Delos and Rhenia islands display three structural domains ([Fig. 7] and [Fig. 8]): (i) the first domain, located in northern Rhenia, is constituted by migmatitic paragneisses (metagreywackes or meta-psammites: Fig. 9e), and displays a domal-like structure; (ii) the second domain, located in a thin (maximum $1 \mathrm{~km}$ width) band in southern Rhenia, is also made of migmatitic paragneisses and is characterized by steeply plunging foliation planes; and (iii) the third domain, located in the southeastern part of Rhenia and in the major part of Delos, is made of several sheets of granitoids.

\subsection{The domal domain}

In this domain, migmatitic paragneisses exhibit a flat foliation and are sometimes intruded by sills of fine-grained biotite granite mainly in the south (Fig. 7). The migmatites are poorly evolved, with a maximum of $30 \%$ of leucosomes (metatexites). The melanosomes show strong plano-linear fabrics and the leucosomes are transposed along the foliation planes (Fig. 9a). Foliation trajectories in northern Rhenia define half-dome with a N-dipping major axis (Fig. 8a). Foliation trajectories in the northern half of southern Rhenia define a second dome isolated from the northern one by a synform. Stretching lineations are shown by the elongation of K-feldspar and quartz grains and by the arrangement of phyllosilicates around a zone axis. 59 lineations were measured in the foliation plane: they show a homogeneous orientation with a slight westerly plunge and a mean direction at $262^{\circ} \mathrm{E}$ (Fig. $7 \mathrm{~b}$ ). The fabric is generally plano-linear (Fig. 9b) with the exception of the western side of Rhenia where the lineation is difficult to determine (Fig. 9c). In thin sections, kinematic indicators of noncoaxial deformation support homogeneous top-to-the-east shearing in the whole sector (Fig. 9c). In domains located close to the dome core, many meter-scale folds with north- 
dipping axial planes and axes parallel to the stretching lineation are observed (Fig. 9d).

Finally, in many outcrops, like in the Mykonos laccolith, veins filled by greenschist facies minerals (epidote + albite + chlorite + quartz) and striking perpendicular to the foliation can be observed.

\subsection{The transitional domain}

This domain consists in migmatitic paragneisses intruded by dikes of fine-grained biotite granite and is characterized by steeply south-dipping foliation planes with $66^{\circ} \mathrm{E}$ mean strike ([Fig. 7] and [Fig. 9]f). Tight folds with steep axial planes roughly parallel to the foliation (Fig. 8g) and axes parallel to the stretching lineation can be observed at different scales, from the outcrop scale as metric and millimetric folds (Fig. 9g) to the map scale where the foliation of this domain shows an antiformal structure slightly overturned to the south (Fig. 8b). The lineations strike homogeneously $253^{\circ} \mathrm{E}$ with a slight westerly plunge (Fig. $7 \mathrm{~b}$ ).

\subsection{The sheets of granitoids}

This domain is constituted by several sheets of granitoids similar to those observed in the Mykonos laccolith. They form EW-striking bands with, from north to south, biotite monzogranite, biotite and hornblende monzogranite and pyroxene granodiorite (Fig. 7). These rocks record an intense magmatic deformation marked by euhedral feldspar phenocrysts with their long axis aligned along (Fig. 9j) an EW-trending, slightly east-plunging lineation carried by an E-W to NE-SW steeply dipping foliation plane (Fig. 7). Thin section observations (Fig. 9h) show submagmatic microstructures devoid of any solid-state deformation in quartz and feldspar. Formation of fractures in feldspar with eutectic recrystallisation seems to correspond to the late stage of this magmatic deformation (Fig. 9j). Fabric is strongly linear as shown by our field measurement of the aspect ratio of enclaves (Fig. 9i) as well as those made by Lucas (1999). A sheet 30 m-thick of biotite monzogranite lies at the contact with the micaschists; the contact is generally sharp and parallel to the foliation plane of the micaschists. The biotite monzogranite also crops out in the center of the plutonic sheet as $\mathrm{cm}$-thick vertical layers in the biotite and hornblende monzogranite. Sometimes, the biotite monzogranite is included in the amphibole monzogranite with intervening quartzo-feldspatic veins at the contact. Finally, within the basement, the biotite monzogranite form dykes trending generally parallel to the gneissic foliation. Biotite and hornblende monzogranite forms a $1 \mathrm{~km}$-wide sheet in contact with the biotite monzogranite to the north and a $1 \mathrm{~km}$-wide sheet of pyroxene granodiorite to the south. The contacts between these three units are sharp and are associated with magmatic layering. In the south of the pyroxene granodiorite sheet we observe an alternation of pyroxene granodiorite and biotite/hornblende monzogranite bodies characterized by subhorizontal magmatic foliations. This sector corresponds to the development of the major body of the laccolith in the border of the magmatic sheet.

\section{Interpretation of the observations and discussion}

\subsection{Evidence for a continuum of deformation in the Mykonos laccolith from its emplacement to the late stages of cooling}

The Mykonos granitoids design a kilometer-scale sub-elliptical body with subhorizontal foliations and with a rather flat and concordant basal surface, as well as a sheeted complex on several kilometers. It can thus be considered as an asymmetrical laccolith-like intrusion (e.g. 
Roman-Berdiel et al., 1995) with an outlying root zone to the SW cropping out on Delos and Rhenia islands (Fig. 10b) and a major body mainly developed to the ENE and cropping out on Mykonos island. The major body displays a sub-elliptical and skirt shape with a ca. $\mathrm{N} 70^{\circ} \mathrm{E}$ long axis (Fig. 10); it developed both at the interface between the Cycladic Basement and the Blueschist Unit and within the Blueschist Unit as shown by the presence of micaschist levels close to the basal contact and the presence of micaschists xenoliths in the laccolith (Fig. 1b). The top of the laccolith intruded the Upper Cycladic Unit, and the granitoids grew progressively upward across the Blueschist Unit probably by ballooning. The mineralogical zonation with sharp contacts in the main body and in the sheeted complex in the SW pluton margin of Delos demonstrates a protracted intrusion forming by successive pulses. Enclaves of felsic granites in more basic ones indicate a later emplacement of mafic magmas. Moreover the more basic facies constitute the bottom of the laccolith (Fig. 10b) suggesting emplacement of the final pulses by under-accretion (Menand, 2008). The total pluton thickness is not directly observable, but scaled cross sections suggest a total thickness of approximately 2 to $3 \mathrm{~km}$ (Fig. 6). The total volume of the pluton is estimated approximately $150 \mathrm{~km}^{3}$. de Saint Blanquat et al. (2010) proposed from references to several pluton systems that "pluton size is closely tied to the time required for pluton assembly"; applying the empirical relationship derived by these authors suggests that the Mykonos laccolith probably emplaced within a 10,000 year time span.

The laccolith shows evidence of three stages of deformation that probably occurred in the same tectonic setting. The older deformation is recorded in the root zone of the pluton and is characterized by submagmatic microstructures, E-W horizontal lineations and subvertical foliation planes. Horizontal submagmatic lineations in the root zone are strictly parallel to those observed in country rocks in the Rhenia island where these lineations are carried by horizontal foliation planes suggesting that the sheeted complex structuration is partly due to regional extension. Indeed, the stretching lineations in paragneisses are homogeneous and so likely formed in a direction parallel to the regional extension. In contrast, subvertical magmatic foliations in the root zone that are associated with an important tilting of paragneissic foliation and subvertical upright folding at the contact with the root zone certainly reflect the forces generated by the forceful intrusion. Together with those of Lucas (1999), our observations additionally show that the fabric is strongly prolate in the root zone of the laccolith and thus is associated with a constrictional deformation. This constrictional deformation could be the result of the complex interaction between shortening due to the forceful intrusion and regional vertical shortening associated with regional extension.

The second event of deformation is recorded in the whole laccolith and is characterized by high to middle temperature protomylonitic microstructures. These microstructures developed after the emplacement of the laccolith in solid-state conditions and probably just after the complete solidification of the pluton system. Indeed the temperature prevailing during the formation of these microstructures are in the range $950{ }^{\circ} \mathrm{C}-600{ }^{\circ} \mathrm{C}$ obtained by Lucas (1999) by using thermometry on hornblende and biotite. The relative microstructural homogeneity in the laccolith may be due to the successive pulses of intrusion: each sheet intruding a nonconsolidated earlier one and all pulses were later deformed after the complete solidification of the pluton system. This event is characterized by a less inclined foliation and a N70 $\mathrm{E}-$ trending mean lineation. Such structural characteristics are close to those observed in country rocks, far (North Rhenia island), near (Appolonion sector) or inside (septas) the laccolith, suggesting that this event of deformation is related to regional extension. Whereas the laccolith shows an overall microstructural homogeneity, the evolution of the fabrics, from 
weakly prolate close to its bottom to strongly oblate close to the major detachment plane, likely marks the upward increase of the influence of the detachment.

The latest event of deformation in the Mykonos laccolith corresponds to the localization of deformation at the top of the laccolith. This localisation is marked by formation of low temperature mylonites and cataclasites close to the major detachment fault. Details of deformation in the detachment-fault system of Mykonos are described by Lecomte et al. (2010).

Geochronological and thermochronological data by Brichau et al. (2008) constrain the timing of the three events of deformation recorded by the Mykonos laccolith. U-Pb on zircon, $\mathrm{Ar}-\mathrm{Ar}$ on biotite and hornblende for sample M4 (Fig. 10a; Brichau et al., 2008) located close to the detachment have been reported on the $T-t$ curve on Fig. 10c. We also reported on this diagram data for the low-temperature thermochronometers, zircon and apatite fission track (ZFT and AFT), zircon and apatite (U-Th)/He ages (ZHe and AHe) for sample M4 and for sample M1 located on the Appolonion peninsula. Whereas the ages obtained show relatively important uncertainties, their compilation constrains in detail the cooling history of the Mykonos footwall. Cooling ages from the low-temperature thermochronometers show an overall decrease from west to east in the direction of the tectonic transport of the hanging wall (Fig. 10c). This indicates that the dominant cause of cooling during the last events was tectonic unroofing (e.g. [Brichau et al., 2008], [Foster and John, 1999] and [Foster et al., 2001]). For a sample located far from the detachment (sample M1), the cooling curve (Fig. 10c) presents a steep slope. This suggests that the cooling history of this sample was very fast. If the brittle/ductile transition occurs around a temperature of $300{ }^{\circ} \mathrm{C}$ (Stöckhert et al., 1999), then the development of HT-MT mylonites in the western part of the Mykonos laccolith occurred during 1 Ma maximum. For a sample located close to the detachment (sample M4), the cooling curve displays a less steep slope with a steady mean cooling rates of $125^{\circ} \mathrm{C} / \mathrm{Ma}$ (Brichau et al., 2008; Fig. 10c). This suggests that the formation of HT-MT mylonites could have occurred during $3 \mathrm{Ma}$ in this sector. Finally, the cooling history of sample M4 indicates that the formation of the low-temperature ultramylonites and cataclasites at the top of the laccolith could have occurred after ca. $10.5 \mathrm{Ma}$, i.e. $3 \mathrm{Ma}$ after the intrusion.

\subsection{Evidence for a rotation of the Mykonos laccolith around a vertical axis during its exhumation}

Paleomagnetic studies performed by Morris and Anderson (1996) on Mykonos island highlight a clockwise rotation around a vertical axis of the Mykonos granite by ca. $22^{\circ}$. This rotation affected both the Upper Cycladic Unit and the Mykonos laccolith during the activity of the Mykonos brittle detachment (Lecomte et al., 2010). If the overall curvature of the lineations (Fig. 10a) in the granite is also due to this rotation, it would imply a local rotation greater than $22^{\circ}$. Alternatively, we could explain the progressive evolution of stretching markers in the laccolith by: (i) a change in the regional direction of extension during deformation of the laccolith; (ii) a competition between deformation related to the dynamics of magma emplacement and the regional extensional deformation as proposed for the Tinos pluton (de Saint Blanquat et al., 2010). The first alternative hypothesis is not viable because of the progressive evolution of the stretching lineation in sectors characterized by the same temperature of deformation. The second alternative hypothesis implies that the orientation of stretching lineation in the root zone is strongly influenced by magma-injection processes that caused constrictional deformation in the root zone with a $\mathrm{N} 90^{\circ} \mathrm{E}-$ directed stretching.

Curvature of lineations in the laccolith would correspond to a progressive rotation away from 
the sheeted complex and therefore to an increase of deformation controlled by regional extension, oriented $c a . \mathrm{N} 20^{\circ} \mathrm{E}$. However, the stretching lineations in the Rhenian parageneisses away from the intrusion-affected zone (i.e. the domal domain) that recorded the regional extensional direction are strictly parallel to the lineations of the sheeted complex. Moreover the associated fabrics are plano-linear to planar and never linear contrary to the root zone.

We propose that the overall curvature of lineations recorded in the Mykonos laccolith is due to differential block rotations on it both sides during its exhumation as proposed for the Rhodope core complex by Brun and Soukoutis (2007). Decoupling between hangingwall and footwall of the NCDS occurred during its activity to accommodate their differential rotation. In this model, the formation of the stretching lineation occurred first in the ductile crust at high to middle temperature conditions. During subsequent exhumation and cooling of the laccolith, successive parts of the laccolith were incorporated in the upper crust where the lineations were frozen ([Brun and Soukoutis, 2007] and [Brun and Van Den Driessche, 1994]). The successively exhumed parts of the laccolith have recorded the progressive differential block rotation. Consequently, the lineations in granites form arcs around a pole of rotation. Fig. 10a illustrates the best-fit circles that can be obtained from the pattern of lineations at the scale of the Mykonos laccolith. They correspond to a pole located about $12 \mathrm{~km}$ to the north of Delos island. The amount of local clockwise rotation around a vertical axis recorded by the Mykonos laccolith during its exhumation can be estimated at about $60^{\circ}$. On the Rhenia and Delos islands stretching lineations in granitoids and gneisses are homogenously EW oriented. These lineations do not show the progressive variation in orientation observed in the Mykonos laccolith stricto sensu. Thus, the exhumation of the Rhenia gneisses and of the sheeted complex occurred before the beginning of the local rotation. This sector underwent a prerotation exhumation in contrast to the syn-rotation exhumation recorded in the whole laccolith.

In a synthesis on paleomagnetic data combined with a synthesis of the orientation of stretching lineations on the Aegean domain, Walcott and White (1998) proposed that extension started in the Late Oligocene-early Miocene in a N23 ${ }^{\circ} \mathrm{E}$ direction. Around $25 \mathrm{Ma}$, Walcott and White (1998) demonstrate that there was a division of the Aegean crust into the West Aegean Block and the Eastern Aegean block separated by the Mid-Cycladic lineament which corresponds to a fracture zone (Fig. 11, Gautier, 1995). Between $25 \mathrm{Ma}$ and $3 \mathrm{Ma}$ the West Aegean domain Block underwent $\sim 20^{\circ}$ clockwise rotation, whilst the eastern Aegean underwent, on average, $\sim 19^{\circ}$ anticlockwise rotation. Many authors describe this rotation in the Aegean domain with little variation in amplitude ([Kissel and Laj, 1988], [Kissel et al., 1986], [Morris and Anderson, 1996] and [van Hinsbergen et al., 2005]). The northern limit of the West Aegean Block has been identified by Kissel et al. (1995) as the Scutari-Pec zone in the northern Albania which forms the transition from no significant post-Eocene rotations in the Dinarides to a $20^{\circ}$ clockwise rotation in the Albano-Hellenides. Finally, several authors have proposed that the West Aegean block corresponds to an assemblage of smaller units that have individually accommodated variable amounts of translation and rotation superimposed to the overall rigid rotation of the large block. In a consistent way, we propose that the Mykonos MCC, located at the southern limit of the West Aegean block, record the ca. $20^{\circ}$ overall rotation of the West Aegean block plus a ca. $60^{\circ}$ local rotation (Fig. 11). Such high amplitude of rotation was recorded by paleomagnetic data in various sector of West Aegean block such as the pre-apulian zone of Levkas (van Hinsbergen et al., 2005). The true direction of extension can be obtained by using a counterclockwise correction of $20^{\circ}$ on the stretching markers observed just below the detachment and thus correspond to a direction close to $\mathrm{N} 10^{\circ} \mathrm{E}$. There was probably no variation of these direction during extensional deformation in 
the Mykonos MCC. The T-t curve (Fig. 10c) indicates that the granite near Appolonion cooled below $300{ }^{\circ} \mathrm{C}$ at around $13 \mathrm{Ma}$, while the granite closer to the detachment, further east, reached the same temperature at around $10 \mathrm{Ma}$. If we consider a temperature of $300{ }^{\circ} \mathrm{C}$ for the brittle-ductile transition and that the exhumation history of the Mykonos granitoids is rather simple and corresponds to a single event, then we can constrain the period of local rotation between $c a .13$ and $10 \mathrm{Ma}$. This local rotation of $c a .60^{\circ}$ recorded during exhumation of the Mykonos MCC was not measured by Morris and Anderson (1996). In their study, the magnetisation of the granodiorites was mainly carried by pyrrhotite with an unblocking temperature of $\sim 320^{\circ} \mathrm{C}$ (van Hinsbergen et al., 2005), which is a temperature typical for the brittle-ductile transition. We saw above that the rotation of the ductile lineations in the Mykonos MCC occurred in the upper crust above the transient brittle-ductile transition. Because the unblocking temperature of pyrrhotite and the temperature of the brittle-ductile transition are very close, we suggest that the local rotation recorded in the Mykonos MCC by the stretching markers was not recorded by mineral remanence.

\subsection{Development of the Mykonos metamorphic core complex}

Studying the role of granitic intrusion on the development of the MCC requires that the spatial and temporal relationships between these two objects be tightly constrained. Several evidences show that the intrusion of the Mykonos laccolith has affected the foliation of the Rhenia domal domain where the leucosomes of migmatites is transposed (see Section 4 and Fig. 7). This demonstrates that the development of the Rhenia dome began before the intrusion of the Mykonos laccolith, as already observed in the Aegean Naxos migmatitic dome and Naxos granodiorite (e.g. Jolivet et al., 2004).

\subsubsection{Initiation of the Mykonos MCC}

The first stage of deformation recorded in the Mykonos MCC is marked by more or less flat shearing toward the N-NE and partial melting of lower crustal paragneisses (Fig. 12aA). A continuum of multi-scale folding occurred in the lower crustal material with two main axes, perpendicular and parallel to the stretching direction. This folding stage led to the formation of a domal structure in the Rhenia paragneisses (Fig. 12aB), this dome displays intermediate characteristics between the Tinos dome with a long axis perpendicular to the stretching direction (b-type dome, Jolivet et al., 2004) and the migmatitic dome of Naxos with long axis parallel to the stretching lineation (a-type dome). We concur with (Avigad et al., 2001) and (Jolivet et al., 2004) that this double-axis folding and non-coaxial shearing is the result of the interplay between regional $\mathrm{N} 20^{\circ} \mathrm{E}$ extension and $\mathrm{E}-\mathrm{W}$ shortening which is recorded early in the Aegean extensional domain. Regional non-coaxial extension to the east led to a contemporaneous $\mathrm{N}-\mathrm{S}$ boudinage and development of a plano-linear fabric associated with $\mathrm{N}-\mathrm{NE}$ shearing in the paragneisses. E-W shortening is marked by formation of folds parallel to lineations observed at different scales in the northern part of Rhenia island. The formation of the migmatitic dome is associated with boudinage in the upper crust and the Cycladic Blueschists tend to fill the gaps between the boudins (Jolivet et al., 2010).

\subsubsection{Emplacement of the Mykonos laccolith}

At 13.5 Ma, granites and granodiorites of the Mykonos laccolith have intruded the Blueschist Unit at the top of the migmatitic domain (Fig. 12aB). The laccolith developed by successive pulses of magmas in short time intervals as suggested by petrological observations and by volume estimates. Geochemical analysis performed by Lucas (1999) on whole rock in the 
Mykonos laccolith suggest that the magmas is issued from infra-crustal melting which induced the formation of an infra-crustal magma chamber. The magma chamber was drained from top to the bottom and allowed the formation of a pluton with an inverted petrographic zonation. More recently, Stouraiti et al. (2010) demonstrated, with references from numerous plutons, that generation of the Cyclades I- and S-type granitoids is due to crustal partial melting and does not requires mantle-derived component as suggested in previous studies ([Altherr and Siebel, 2002] and [Altherr et al., 1988]). The dominant source identified by Stouraiti et al. (2010) corresponds to metasedimentary biotite gneiss as the metagreywackes of Rhenia. These authors also highlighted the possible contribution of a Ca-rich component and have demonstrated that the third source component corresponds to amphibolite.

After its emplacement the laccolith was affected by an intense non-coaxial deformation (top to the N-NE) which started at the end of crystallization. This deformation was associated with a rapid cooling marked by conditions evolving from submagmatic to semi-ductile in a short time span (Fig. 10c). Considering the present relative location of the laccolith and the NCDS, but also the rapid cooling of the laccolith, the development of a penetrative protomylonitic fabric in the granites and the later low-temperature deformation at the head of the laccolith, we propose that the Mykonos laccolith intruded the Cycladic Blueschist Unit close to the NCDS which corresponds to a large detachment system affecting the upper crust and the brittle/ductile transition. In this scenario, the necking of the Aegean upper crust would have acted as an attractor for the upward rise of Miocene magmas.

\subsubsection{Exhumation of the Mykonos MCC}

As mentioned above, thermochronological data by Brichau et al., 2008 show that exhumation of the Mykonos laccolith was very fast. Moreover, ages obtained from the low-temperature thermochronometers decrease from west to east (Fig. 10c) and are thus consistent with the model of local rotation that we proposed. Just after the period of emplacement, the root zone of the laccolith and the migmatitic gneisses of Rhenia were incorporated in the upper crust and then underwent rigid clockwise rotations (Fig. 12aC). A period of ca. 3 Ma was necessary for the exhumation of the other fringes of the laccolith. During this period, differential rotations of upper crustal blocks linked to a decoupling of the hangingwall and footwall of the NCDS remained rigid over the whole domain as shown by the regular curvature of the protomylonitic lineations. Exhumation of the last fringe of the laccolith is contemporaneous with a phase of strong deformation just below the detachment in semi-ductile conditions as shown by the presence of the low-temperature ultramylonitic bands in the head of the laccolith. Then deformation continued in brittle conditions and cataclastic granites developed close to the detachment. The end of the period of activity of the detachment is coeval with the emplacement of huge barite veins. The normal faults of Panormos clearly postdate the detachment and the barite veins and represent the latest structures of the Mykonos island.

\subsection{Limited triggering effect of granitic intrusion on the development of MCC in the Aegean domain}

Our study of the evolution of deformation on a two-kilometer crustal cross-section in the Mykonos pluton intruding a MCC beneath the Nord Cycladic detachment provides further insights into the role of magmatitic intrusion on MCC development.

An important result is that the Mykonos intrusion postdates the initiation of the migmatitic dome of Rhenia. This interpretation is consistent with studies in the two islands surrounding 
Mykonos. In Naxos island to the south, the formation of the migmatitic core complex is considered to be older than 20-21 Ma by $\mathrm{U} / \mathrm{Pb}$ dating on zircon crystals from migmatite samples ([Keay et al., 2001] and [Martin et al., 2006]) and the roof of the dome is intruded by a granodioritic pluton dated around $12 \mathrm{Ma}$ ([Andriessen et al., 1979], [Keay et al., 2001] and [Wijbrans and McDougall, 1986]). To the north, in the relative low-temperature greenschist facies dome of Tinos, initiation of boudinage and top to the NE shearing started some $30 \mathrm{Ma}$ ago ([Bröcker, 1990], [Bröcker and Franz, 1998] and [Parra et al., 2002]) and the top of the dome was later intruded by a pluton dated about 14-15 Ma ([Avigad and Garfunkel, 1989] and [Brichau et al., 2007]). This strongly suggests that the Cycladic plutonism event had no significant role on the initiation of MCC.

The Mykonos asymmetric laccolith recorded extensional non-coaxial finite strain related to $\mathrm{N} 20^{\circ} \mathrm{E}$ extension. This type of asymmetric laccolith associated with non-coaxial deformation was also evidenced by other field studies ([Acocella, 2000], [Baldwin et al., 1993], [Guillot et al., 1993], [Le Fort et al., 1987] and [Roig and Faure, 1995]) and by anologue modeling (Roman-Berdiel et al., 1995). The internal deformation recorded by the laccolith after its crystallization remained relatively low compared to the strong non-coaxial deformation recorded by the gneissic country-rocks, the reason why one can still observe submagmatic microstructures in the granite. Consequently, there is no strong localisation of deformation in granites after their crystallization. By contrast, the geometry of the intrusion shows that the magmas were strongly "sucked" into the direction of regional extension. This observation suggests that the emplacement of the laccolith will likely cause a local acceleration of the MCC development and of the slip rate along the detachment. Very fast cooling and exhumation of the laccolith can be linked to this acceleration. The important local rotation of upper-crustal blocks during the exhumation of the laccolith could be due also to the local acceleration of the slip rate on the detachment. Thus the Mykonos granite promoted MCC development at least in the final stages. At the scale of the Aegean domain this role seems to be limited in space and time and the emplacement of plutons occurred later than the initiation of MCC (by $15 \mathrm{Ma}$ in Tinos and by $10 \mathrm{Ma}$ in Mykonos and Naxos). Moreover, this role is limited in space as shown by the relative reduced amount of Miocene plutons in the Cyclades compared to the ubiquity of MCC (Fig. 1a).

Various numerical modeling of Aegean core complexes involved a pre-existing viscositydensity anomaly below the brittle-ductile transition ([Brun et al., 1994], [Tirel et al., 2004] and [Tirel et al., 2008]). Our field study shows that such a pre-existing anomaly cannot be a laccolith pluton. In contrast, partial melting of Aegean crust predated emplacement of pluton and could therefore have acted as such anomaly. The triggering effect of granite intrusion on MCC development is clearly limited to the youngest stages. Note however that this is not the case in MCC observed in other orogens like in the Variscan belt where plutonism is ubiquist in all the stages of orogenic evolution. In the south Basin and Range province, the South Mountain core complex formation coincides exactly in space and time with plutonic intrusion events ([Lister and Baldwin, 1993] and [Reynolds, 1985]). Further north, in the IdahoBitterroot batholith the youngest intrusions are nearly of the same age than the initial collapse of the orogen and extension (Foster et al., 2001).

\section{Conclusion}

The Mykonos metamorphic core complex is characterized by the emplacement of a kilometerscale laccolith-like intrusion. Our study of the interaction between MCC formation and laccolith emplacement demonstrates the later emplacement of the granites. 
The geometry of the laccolith, its internal deformation, the deformation recorded by its country-rocks and previously published geochronological data demonstrate that the emplacement of the laccolith accelerates the final stage of MCC exhumation. Final exhumation is accommodated by an intense local clockwise rotation around a vertical axis of upper crustal blocks, as shown by the stretching markers. During this rotation, major uncoupling occurs between hanging-wall and footwall of the NCDS which corresponds to a major detachment system.

Finally, reconstitution of the pre-rotation structure shows that the entire cycladic ductile crust was stretched along a direction close to $\mathrm{N} 10^{\circ} \mathrm{E}$ during the Oligo-Miocene extension. This unique direction of stretching in the crust is parallel to the direction of the mantle fabric measured by seismic anisotropy (Jolivet et al., 2009). Compilation of crustal and mantle direction indicates that all the Aegean lithosphere was subjected to an important NS stretching during Oligo-Miocene extension.

\section{Acknowledgments}

This paper is a contribution of the ANR EGEO project. We thank S. Rousse and Ph. Olivier for constructive discussions. We also thank two anonymous reviewers and F. Storti for their valuable remarks which helped to improve the first version of this article.

\section{References}

Acocella, $2000 \mathrm{~V}$. Acocella, Space accommodation by roof lifting during pluton emplacement at Amiata (Italy), Terra Nova 12 (2000), pp. 149-155.

Altherr and Siebel, 2002 R. Altherr and W. Siebel, I-type plutonism in a continental back-arc setting: Miocene granitoids and monzonites from the central Aegean Sea, Greece, Contrib. Mineral. Petrol. 143 (2002), pp. 397-415

Altherr et al., 1982 R. Altherr, H. Kreuzer, I. Wendt, H. Lenz, G.A. Wagner, J. Keller, W. Harre and A. Hohndorf, A Late Oligocene/Early Miocene high temperature belt in the anticycladic crystalline complex (SE Pelagonian, Greece), Geol. Jahrb. 23 (1982), pp. 97-164.

Altherr et al., 1988 R. Altherr, F.J. Henjes-Klunst, A. Matthews, H. Friedrichsen and B.T. Hansen, $\mathrm{O}-\mathrm{Sr}$ isotopic variations in Miocene granitoids from the Aegean: evidence for an origin by combined assimilation and fractional crystallisation, Contrib. Mineral. Petrol. 100 (1988), pp. 528-541

Andriessen et al., 1979 P.A.M. Andriessen, N.A.I.M. Boelrijk, E.H. Hebeda, H.N.A. Priem, E.A.T. Verdurmen and R.H. Vershure, Dating the events of metamorphism and granitic magmatism in the Alpine orogen of Naxos (Cyclades, Grèce), Contrib. Mineral. Petrol. 69 (1979), pp. 215-225.

Aoya et al., 2005 M. Aoya, S.R. Wallis, K. Terada, J. Lee, T. Kawakami, Y. Wang and M. Heizler, North-south extension in the Tibetan crust triggered by granite emplacement, Geology 33 (2005), pp. 853-856. 
Avigad and Garfunkel, 1989 D. Avigad and Z. Garfunkel, Low-angle faults above and below a blueschist belt: Tinos Island, Cyclades, Greece, Terra Nova 1 (1989), pp. 182-187.

Avigad et al., 1998 D. Avigad, G. Baer and A. Heimann, Block rotations and continental extension in the Central Aegean Sea: paleomagnetic and structural evidence from Tinos and Mykonos, EPSL 157 (1998), pp. 23-40.

Avigad et al., 2001 D. Avigad, A. Ziv and Z. Garfunkel, Ductile and brittle shortening, extension-parallel folds and maintenance of crustal thickness in the Central Aegean, Tectonics 20 (2001), pp. 277-287.

Baldwin et al., 1993 S.L. Baldwin, G.S. Lister, E.J. Hill, D.A. Foster and I. McDougall, Thermochronologic constraints on the tectonic evolution of active metamorphic core complexes, D'Entrecasteaux Islands, Papua New Guinea, Tectonics 12 (1993), pp. 611-628.

Blake et al., 1981 M.C. Blake, M. Bonneau, J. Geyssant, J.R. Kienast, C. Lepvrier, H. Maluski and D. Papanikolaou, A geological reconnaissance of the Cyclacic blueschist belt, Greece, Bull. Geol. Soc. Am. 92 (1981), pp. 247-254.

Bonneau, 1984 M. Bonneau, Correlation of the Hellenic nappes in the south-east Aegean and their tectonic reconstruction. In: J.E. Dixon and A.H.F. Robertson, Editors, The Geological Evolution of the Eastern Mediterranean, Geol. Soc. Lond. Spec. Publ. 17 (1984), pp. 517-527.

Borradaile and Henry, 1997 G.J. Borradaile and B. Henry, Tectonic applications of magnetic susceptibility and its anisotropy, Earth Sci. Rev. 42 (1997), pp. 49-93.

Borradaile and Jakson, 2010 G.J. Borradaile and M. Jakson, Structural geology, petrofabrics and magnetic fabrics (AMS, AARM, AIRM), J. Struct. Geol. 32 (2010), pp. 1519-1551.

Bouchez, 1997 J.L. Bouchez, Granite is never isotropic: an introduction to AMS studies of granitic rocks. In: J.-L. Bouchez, D.H.W. Hutton and W.E. Stephens, Editors, Granite: from Segregation of Melt to Emplacement Fabrics, Kluwer Academic Publishers, Dordrecht (1997), pp. 95-112.

Bouchez, 2000 J.L. Bouchez, Anisotropie de susceptibilité magnétique et fabrique des granites, C. R. Acad. Sci. Paris 330 (2000), pp. 1-14.

Brandon and Vance, 1992 M.T. Brandon and J.A. Vance, Tectonic evolution of the Cenozoic Olympic subduction complex, Washington State, as deduced from fission-track ages for detrital zircons, Am. J. Sci. 292 (1992), pp. 565-636.

Brandon et al., 1998 M.T. Brandon, M.K. Roden-Tice and J.I. Garver, Late Cenozoic exhumation of the Cascadia accretionary wedge in the Olympic Mountains, NW Washington State, Geol. Soc. Am. Bull. 110 (1998), pp. 985-1009.

Brichau et al., 2007 S. Brichau, U. Ring, A. Carter, P. Monié, D. Stockli and M. Brunel, Extensional faulting on Tinos Island, Aegean Sea, Greece: how many detachments?, Tectonics 26 (2007), p. TC4009 10.1029/2006TC001969 19 pp.. 
Brichau et al., 2008 S. Brichau, U. Ring, A. Carter, R. Bolhar, P. Monié, D. Stockli and M. Brunel, Timing, slip rate, displacement and cooling history of the Mykonos detachment footwall, Cyclades, Greece, and implications for the opening of the Aegean Sea basin, J. Geol. Soc. Lond. 165 (2008), pp. 263-277.

Bröcker, 1990 M. Bröcker, Blueschist-to-greenschist transition in metabasites from Tinos island, Cyclade, Greece: compositional control or fluid infiltration, Lithos 25 (1990), pp. 2539.

Bröcker and Franz, 1998 M. Bröcker and L. Franz, Rb-Sr isotope studies on Tinos island (Cyclades, Greece): additional time constraints for metamorphism, extent of infiltrationcontrolled overprinting and deformational activity, Geol. Mag. 135 (1998), pp. 369-382.

Brun and Soukoutis, 2007 J.-P. Brun and D. Soukoutis, Kinematics of the Southern Rhodope Core Complex (North Greece), Int. J. Earth Sci. (Geol Rundsch) 96 (2007), pp. 1079-1099.

Brun and Van Den Driessche, 1994 J.-P. Brun and J. Van Den Driessche, Extensional gneiss domes and detachment fault systems: Structure and kinematics, Bull. Soc. Geol. France 165 (1994), pp. 519-530.

Brun et al., 1994 J.-P. Brun, D. Soukoutis and J. Van Den Driessche, Analogue modeling of detachment fault systems and core complex, Geology 22 (1994), pp. 19-22.

Buck, 1993 W.R. Buck, Effect of lithospheric thickness on the formation of high- and lowangle normal faults, Geology 21 (1993), pp. 933-936.

Cherniak and Watson, 2000 D.J. Cherniak and E.B. Watson, $\mathrm{Pb}$ diffusion in zircon, Chem. Geol. 172 (2000), pp. 5-24.

Coney and Harms, 1984 P.J. Coney and T.A. Harms, Cordilleran metamorphic core complexes, Cenozoic extensional relics of Mesozoic compression, Geology 12 (1984), pp. $550-554$.

Crittenden et al., 1980 In: M.D.J. Crittenden, P.J. Coney and G.H. Davis, Editors, Cordilleran Metamorphic Core Complexes (1980) 490 pp..

Dahl, 1996a P.S. Dahl, The crystal-chemical basis for argon retention in micas: inferences form interlayer partitioning and implications for geochronology, Contrib. Mineral. Petrol. 123 (1996), pp. 22-39.

Dahl, 1996b P.S. Dahl, The effects of composition on retentivity of argon and oxygen in hornblende and related amphiboles: a field-tested empirical model, Geochim. Cosmochim. Acta 60 (1996), pp. 3687-3700.

Daniel and Jolivet, 1995 J.M. Daniel and L. Jolivet, Interaction of detachments and granitic plutons during extension in the Tyrrhenian Sea (Elba island), Bull. Soc. Geol. France 166 (1995), pp. 341-354.

de Saint Blanquat et al., 2010 M. de Saint Blanquat, E. Horsman, G. Habert, S. Morgan, O. Vanderhaeghe, R. Law and B. Tikoff, Multiscale magmatic cyclicity, duration of pluton 
construction, and the paradoxical relationship between tectonism and plutonism in continental arcs, Tectonophysics (2010) 10.1016/j.tecto.2009.12.009.

Denèle et al., 2008 Y. Denèle, Ph. Olivier and G. Gleizes, Progressive deformation of a zone of magma transfer in a transpressional regime: the Variscan Mérens shear zone (Pyrenees, France), J. Struct. Geol. 30 (2008), pp. 1138-1149.

Donelick, 1991 R.A. Donelick, Crystallographic orientation dependence of mean etchable fission track length in apatite: an empirical model and experimental observation, Am. Mineral. 76 (1991), pp. 83-91.

Faure et al., 1991 M. Faure, M. Bonneau and J. Pons, Ductile deformation and syntectonic granite emplacement during the late Miocene extension of the Aegean (Greece), Bull. Soc. Geol. France 162 (1991), pp. 3-12.

Forster and Lister, 2009 M. Forster and G. Lister, Core-complex-related extension of the Aegean lithosphere initiated at the Eocene-Oligocene transition, J. Geophys. Res. 114 (2009), p. B02401 10.1029/2007JB005382 36 pp

Foster and John, 1999 D.A. Foster and B.E. John, Quantifying tectonic exhumation in an extensional orogen with thermochronology: examples from the southern Basin and Range Province. In: U. Ring, M. Brandon, G.S. Lister and S.D. Willett, Editors, Exhumation Processes: Normal Faulting, Ductile Flow and Erosion, Geol. Soc. Lond. Spec. Publ. 154 (1999), pp. 356-378.

Foster et al., 2001 D.A. Foster, C. Schafer, C.M. Fanning and D.W. Hyndman, Relationships between crustal partial melting, plutonism, orogeny, and exhumation: Idaho-Bitterroot batholith, Tectonophysics 342 (2001), pp. 313-350.

Gautier, 1995 Gautier, P., 1995. Géométrie crustale et cinématique de l'extension tardiorogénique dans le domaine centre-égéen: îles des Cyclades et d'Eubée (Grèce). Thèse de Doctorat, Rennes, 385 pp.

Gautier and Brun, 1994 P. Gautier and J.-P. Brun, Crustal-scale geometry and kinematics of late-orogenic extension in the central Aegean (Cylades and Ewia Island), Tectonophysics 238 (1994), pp. 399-424.

Gautier et al., 1993 P. Gautier, J.-P. Brun and L. Jolivet, Structure and kinematics of upper Cenozoic extensional detachment on Naxos and Paros (Cyclades Islands, Greece), Tectonics 12 (1993), pp. 1180-1194.

Gleizes et al., 2001 G. Gleizes, D. Leblanc, Ph. Olivier and J.-L. Bouchez, Strain partitioning in a pluton during emplacement in transpressional regime: the example of the Néouvielle granite (Pyrenees), Int. J. Earth Sci. (Geol Rundsch) 90 (2001), pp. 325-340.

Gleizes et al., 2006 G. Gleizes, G. Crevon, A. Asrat and P. Barbey, Structure, age and mode of emplacement of the Hercynian Bordères-Louron pluton (Central Pyrenees, France), Int. J. Earth Sci. 95 (2006), pp. 1039-1052 
Green et al., 1989 P.F. Green, I.R. Duddy, G.M. Laslett, K.A. Hegarty, A.J.W. Gleadow and J.F. Lovering, Thermal annealing of fission tracks in apatite: 4 - quantitative modelling techniques and extension to geological timescales, Chem. Geol. 79 (1989), pp. 155-182.

Guillot et al., 1993 S. Guillot, A. Pêcher, P. Rochette and P. Le Fort, The emplacement of the Manaslu granite of Central Nepal: field and magnetic susceptibility constraints. In: P.J.

Treolar and M.P. Searle, Editors, Himalayan Tectonics, Geol. Soc. Lond. Spec. Publ. 74 (1993), pp. 413-428.

Harrison, 1981 T.M. Harrison, Diffusion of 40Ar in hornblende, Contrib. Mineral. Petrol. 78 (1981), pp. 324-331.

Harrison et al., 1985 T.M. Harrison, I. Duncan and I. Mc Dougall, Diffusion of ${ }^{40} \mathrm{Ar}$ in biotite: temperature, pressure and compositional effects, Geochim. Cosmochim. Acta 49 (1985), pp. $2461-2468$.

Hext, 1963 G.R. Hext, The estimation of second-order tensors, with related tests and designs, Biometrika 50 (1963), pp. 353-357.

Hirth and Tullis, 1992 J.E. Hirth and G. Tullis, The brittle-plastic transition in experimentally deformed quartz aggregates, J. Geophys. Res. 99 (1992), pp. 11731-11747.

Huet et al., 2009 B. Huet, L. Labrousse and L. Jolivet, Thrust or detachment? Exhumation processes in the Aegean: insight from a field study on Ios (Cyclades, Greece), Tectonics 28 (2009), p. TC3007 10.1029/2008TC002397 27 pp..

Jelinek, 1981 V. Jelinek, Characterization of the magnetic fabric of rocks, Tectonophysics 79 (1981), pp. 563-567.

Jolivet and Brun, 2010 L. Jolivet and J.-P. Brun, Cenozoic geodynamic evolution of the Aegean, Int. J. Earth Sci. (Geol. Rundsch) 99 (2010), pp. 109-138.

Jolivet and Faccenna, 2000 L. Jolivet and C. Faccenna, Mediterranean extension and the Africa-Eurasia collision, Tectonics 19 (2000), pp. 1095-1106.

Jolivet et al., 2004 L. Jolivet, V. Famin, C. Mehl, T. Parra, C. Aubourg, R. Hébert and P. Philippot, Progressive strain localisation, boudinage and extensional metamorphic complexes, the Aegean Sea case. In: D.L. Whitney, C. Teyssier and C.S. Siddoway, Editors, Gneiss Domes in Orogeny, Geol. Soc. Am. Spec. Pap. 380 (2004), pp. 185-210.

Jolivet et al., 2009 L. Jolivet, C. Faccenna and C. Piromallo, From mantle to crust: stretching the Mediterranean, EPSL 285 (2009), pp. 198-209.

Jolivet et al., 2010 L. Jolivet, E. Lecomte, B. Huet, Y. Denèle, O. Lacombe, L. Labrousse, L. Le Pourhiet and C. Mehl, The North Cycladic Detachment System, EPSL 289 (2010), pp. 87104.

Keay et al., 2001 S. Keay, G. Lister and I. Buick, The timing of partial melting, Barrovian metamorphism and granite intrusion in the Naxos metamorphic core complex, Cyclades, Aegean Sea, Greece, Tectonophysics 342 (2001), pp. 275-312. 
Kissel and Laj, 1988 C. Kissel and C. Laj, The tertiary geodynamical evolution of the Aegean arc: a paleomagnetic reconstruction, Tectonophysics 146 (1988), pp. 183-201.

Kissel et al., 1986 C. Kissel, D. Kondopoulou, C. Laj and P. Papadopoulos, New paleomagnetic data from Oligocene formations of northern Aegean, Geophys. Res. Lett. 13 (1986), pp. 1039-1042.

Kissel et al., 1995 C. Kissel, F. Speranza and V. Milicevic, Paleomagnetism of external southern Dinarides and northern Albanides: implications for the Cenozoic activity of the Scutari-Pec shear zone, J. Geophys. Res. 100 (1995), pp. 14999-15007.

Koyi and Skelton, 2001 H.A. Koyi and A. Skelton, Centrifuge modeling of the evolution of low-angle detachments faults from high-angle normal faults, J. Struct. Geol. 23 (2001), pp. $1179-1185$

Lavier et al., 1999 L. Lavier, W.R. Buck and A.N.B. Poliakov, Self-consistent rolling-hinge model for the evolution of large-offset low-angle normal faults, Geology 27 (1999), pp. 11271130 .

Le Fort et al., 1987 P. Le Fort, M. Cuney, C. Deniel, C. France-Lanord, S.M.F. Sheppard, B.N. Upreti and P. Vidal, Crustal generation of the Himalayan leucogranites, Tectonophysics 134 (1987), pp. 39-57.

Le Pichon and Angelier, 1980 X. Le Pichon and J. Angelier, The Aegean Sea, Philos. Trans. R. Soc. Lond. 300 (1980), pp. 357-372.

Lecomte et al., 2010 E. Lecomte, L. Jolivet, O. Lacombe, Y. Denèle, L. Labrousse and L. Le Pourhiet, Geometry and kinematics of Mykonos detachment (Cyclades, Greece): evidence for slip at shallow dip, Tectonics 29 (2010), p. TC5012 10.1029/2009TC002564 22 pp..

Lee and Lister, 1992 J. Lee and G.S. Lister, Late Miocene ductile extension and detachment faulting, Mykonos, Greece, Geology 20 (1992), pp. 121-124.

Lister and Baldwin, 1993 G.S. Lister and S.L. Baldwin, Plutonism and the origin of metamorphic core complexes, Geology 21 (1993), pp. 607-610.

Lister and Davis, 1989 G.S. Lister and G.A. Davis, The origin of metamorphic core complexes and detachment faults formed during Tertiary continental extension in the northern Colorado River region, U.S.A, J. Struct. Geol. 11 (1989), pp. 65-94

Lister et al., 1984 G.S. Lister, G. Banga and A. Feenstra, Metamorphic core complexes of cordilleran type in the Cyclades, Aegean Sea, Greece, Geology 12 (1984), pp. 221-225.

Lucas, 1999 Lucas, I., 1999. Le pluton de Mykonos-Delos-Rhenee (Cyclades, Grèce): un exemple de mise en place synchrone de l'extension crustale. Thèse de doctorat, Orléans, 491 pp.

Malavieille, 1993 J. Malavieille, Late orogenic extension in the mountain belts: insights from the basin and Range and the late Paleozoic Variscan Belt, Tectonics 12 (1993), pp. 1115-1130. 
Martin et al., 2006 L. Martin, S. Duchêne, E. Deloule and O. Vanderhaeghe, The isotopic composition of zircon and garnet: a record of the metamorphic history of Naxos, Greece, Lithos 87 (2006), pp. 174-192.

Mehl et al., 2005 C. Mehl, L. Jolivet and O. Lacombe, From ductile to brittle: evolution and localization of deformation below a crustal detachment (Tinos, Cyclades, Greece), Tectonics 24 (2005), p. TC4017 10.1029/2004TC001767 23 pp..

Mehl et al., 2007 C. Mehl, L. Jolivet, O. Lacombe, L. Labrousse and G. Rimmelé, Structural evolution of Andros island (Cyclades, Greece): a key to the behaviour of a flat detachment within an extending continental crust. In: T. Taymaz, Y. Dilek and Y. Ylmaz, Editors, The Geodynamics of the Aegean and Anatolia, Geol. Soc. Lond. Spec. Publ. 291 (2007), pp. 41-73.

Menand, 2008 T. Menand, The mechanics and dynamics of sills in layered elastic rocks and their implications for the growth of laccoliths and other igneous complexes, EPSL 267 (2008), pp. 93-99.

Morris and Anderson, 1996 A. Morris and M. Anderson, First paleomagnetic results from the Cycladic Massif, Greece, and their implication for Miocene extension directions and tectonic models in the Aegean, EPSL 142 (1996), pp. 397-408.

Ono et al., 2009 T. Ono, Y. Hosomi, H. Arai and H. Takagi, Comparison of petrofabrics with composite magnetic fabrics of S-C mylonite in paramagnetic granite, J. Struct. Geol. 32 (2009), pp. 2-14.

Parra et al., 2002 T. Parra, O. Vidal and L. Jolivet, Relation between deformation and retrogression in blueschist metapelites of Tinos island (Greece) evidenced by chlorite-mica local equilibria, Lithos 63 (2002), pp. 41-66.

Reiners et al., 2004 P.W. Reiners, T.L. Spell, S. Nicolescu and K.A. Zanetti, Zircon (U$\mathrm{Th}) / \mathrm{He}$ thermochronometry: He diffusion and comparisons with ${ }^{40} \mathrm{Ar} /{ }^{39} 39 \mathrm{Ar}$ dating, Geochim. Cosmochim. Acta 68 (2004), pp. 1857-1887.

Rey et al., 2009 P.F. Rey, C. Teyssier and D.L. Whitney, The role of partial melting and extensional strain rates in the development of metamorphic core complexes, Tectonophysics 477 (2009), pp. 135-144

Reynolds, 1985 S.J. Reynolds, Geology of the South Mountains, central Arizona, Ariz. Bur. Geol. Miner. Technol. Bull. 195 (1985) 61 pp., scale 1:24.000.

Ring et al., 2001 U. Ring, P.W. Layer and T. Reischmann, Miocene high-pressure metamorphism in the Cyclades and Crete, Aegean Sea, Greece: evidence for large-magnitude displacement on the Cretan detachment, Geology 29 (2001), pp. 395-398.

Rochette, 1987 P. Rochette, Magnetic susceptibility of the rock matrix related to magnetic fabric studies, J. Struct. Geol. 9 (1987), pp. 1015-1020.

Rochette et al., 1992 P. Rochette, M. Jackson and C. Aubourg, Rock magnetism and the interpretation of anisotropy of magnetic susceptibility, Rev. Geophys. 30 (1992), pp. 209-226. 
Roig and Faure, 1995 J.Y. Roig and M. Faure, La déformation du quartz dans un pluton syntectonique mis en place pendant l'extension Carbonifère supérieure du Massif Central français (le leucogranite de Chambles, Massif du Velay), C. R. Acad. Sci. Paris 321 (1995), pp. 789-796.

Roman-Berdiel et al., 1995 T. Roman-Berdiel, D. Gapais and J.P. Brun, Analogue models of laccolith formation, J. Struct. Geol. 17 (1995), pp. 1337-1346

Sanchez-Gomez et al., 2002 M. Sanchez-Gomez, D. Avigad and A. Heiman, Geochronology of clasts in allochthonous Miocene sedimentary sequences on Mykonos and Paros islands: implications for back-arc extension in the Aegean Sea, J. Geol. Soc. Lond. 159 (2002), pp. 45-60.

Stöckhert et al., 1999 B. Stöckhert, M.R. Brix, R. Kleinschrodt, A.J. Hurford and R. Wirth, Thermochronometry and microstructures of quartz: a comparison with experimental flow laws and predictions on the temperature of the brittle-plastic transition, J. Struct. Geol. 21 (1999), pp. 351-369.

Stouraiti et al., 2010 C. Stouraiti, P. Mitropoulos, J. Tarney, B. Barreiro, A.M. McGrath and E. Baltatzis, Geochemistry and petrogenesis of late Miocene granitoids, Cyclades, southern Aegean: nature of source components, Lithos 114 (2010), pp. 337-352.

Tirel et al., 2004 C. Tirel, J.-P. Brun and E. Burov, Thermomechanical modeling of extensional gneiss domes. In: D.L. Whitney, C. Teyssier and C.S. Siddoway, Editors, Gneiss Domes in Orogeny, Geol. Soc. Am. Spec. Pap. 380 (2004), pp. 67-78.

Tirel et al., 2008 C. Tirel, J.-P. Brun and E. Burov, Dynamics and structural development of metamorphic core complexes, J. Geophys. Res. 113 (2008), p. B04403 10.1029/2005JB003694 25 pp..

Trotet et al., 2001 F. Trotet, L. Jolivet and O. Vidal, Tectono-metamorphic evolution of Syros and Sifnos islands (Cyclades, Greece), Tectonophysics 338 (2001), pp. 179-206.

van Hinsbergen et al., 2005 D.J.J. van Hinsbergen, C.G. Langereis and J.E. Meulenkamp, Revision of the timing, magnitude and distribution of Neogene rotations in the western Aegean region, Tectonophysics 396 (2005), pp. 1-34.

Vanderhaeghe and Teyssier, $2001 \mathrm{O}$. Vanderhaeghe and C. Teyssier, Crustal-scale rheological transitions during late-orogenic collapse, Tectonophysics 335 (2001), pp. 211-228.

Vanderhaeghe et al., 1999 O. Vanderhaeghe, J.-P. Burg and C. Teyssier, Exhumation of migmatites in two collapsed orogens: Canadian Cordillera and French Variscides. In: U. Ring, U. Brandon, G.S. Lister and S.D. Willett, Editors, Exhumation Processes: Normal Faulting, Ductile Flow and Erosion, Geol. Soc. Lond. Spec. Publ. 154 (1999), pp. 181-204.

Vanderhaeghe et al., 2007 O. Vanderhaeghe, C. Hibsch, L. Siebenaller, S. Duchêne, S. Kruckenberg, A. Fotiadis, L. Martin and M. de Saint Blanquat, Penrose conference extending a continent - Naxos Field guide. In: G. Lister, M. Forster and U. Ring, Editors, Inside the Aegean Metamorphic Core Complexes, J. Virt. Explorer 27 (2007)

10.3809/jvirtex.2007.00175. 
Villa et al., 1996 I.M. Villa, B. Grobéty, S.P. Kelley, R. Trigila and R. Wieler, Assessing Ar transport paths and mechanisms for McClure Mountains Hornblende, Contrib. Mineral.

Petrol. 126 (1996), pp. 67-80.

Walcott and White, 1998 C.R. Walcott and S.H. White, Constraints on the kinematics of postorogenic extension imposed by stretching lineations in the Aegean area, Tectonophysics 298 (1998), pp. 155-175.

Whitney and Evans, 2010 D.L. Whitney and B. Evans, Abbrevations for names of rockforming minerals, Am. Mineralog. 95 (2010), pp. 185-187.

Whitney et al., 2004 D.L. Whitney, C. Teyssier and A. Fayon, Isothermal decompression, partial melting, and the exhumation of deep continental crust. In: J. Grocott, B. Tikoff, K.J.W. McCaffrey and G. Taylor, Editors, Vertical Coupling and Decoupling in the Lithosphere, Geol. Soc. Lond. Spec. Publ. 227 (2004), pp. 313-326.

Wijbrans and McDougall, 1986 J.R. Wijbrans and I. McDougall, ${ }^{40} \mathrm{Ar} /{ }^{39} \mathrm{Ar}$ dating of white micas from an alpine high-pressure metamorphic belt on Naxos (Greece); the resetting of the argon isotopic system, Contrib. Mineral. Petrol. 93 (1986), pp. 187-194.

Wolf et al., 1996 R.A. Wolf, K.A. Farley and L.T. Silver, Helium diffusion and low temperature thermochronometry of apatite, Geochim. Cosmochim. Acta 60 (42) (1996), pp. $31-4240$. 


\section{Figures and Tables}

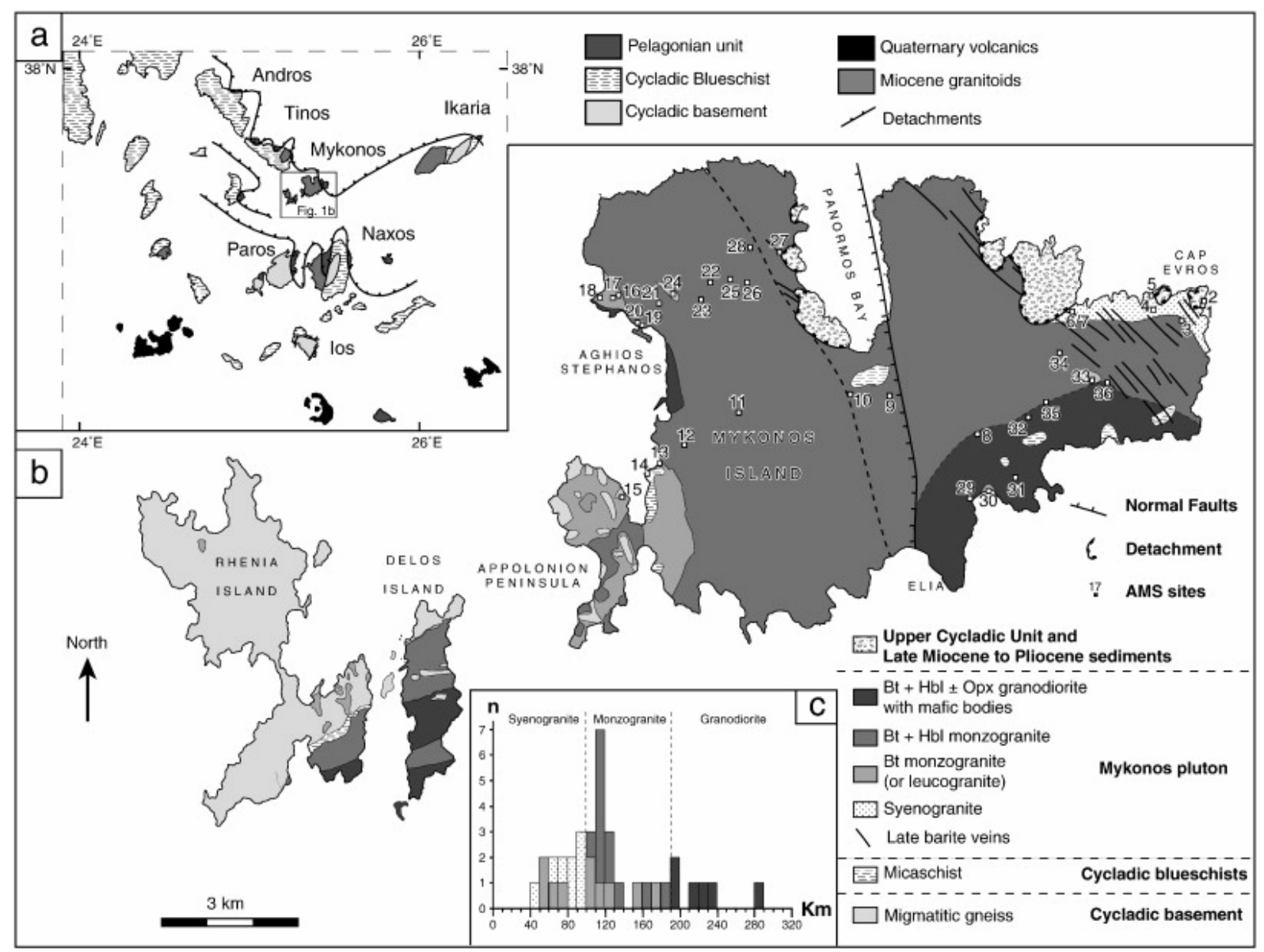

Fig. 1. : (a) Tectonic map of the Aegean region showing the main geological units and the location of the Mykonos-Rhenia-Delos Archipelago (after Huet et al., 2009). (b) Petrographic map of the studied area (after Lucas, 1999 modified) and location of the AMS sites. (c) Histogram of the Mean Susceptibility values $(\mathrm{Km})$.

Table 1. AMS measurements of the plutonic rocks of the Mykonos laccolith. Rt: Rock types, Mf: Magnetic foliation, Ff: Field foliation, Fl: Field lineation, E12, E23, and E31: within-site 
95\% confidence semi-angles (according to the statistics of Hext, 1963) between, respectively, principal axes $\mathrm{K} 1 \mathrm{~K} 2, \mathrm{~K} 2 \mathrm{~K} 3$ and $\mathrm{K} 3 \mathrm{~K} 1$.

\begin{tabular}{|c|c|c|c|c|c|c|c|c|c|c|c|c|c|}
\hline Site & $\mathbf{R t}$ & Mi & $n$ & $K m$ & K1 & Mf & Ff & Fl & $P p \%$ & $T$ & E12 & E23 & E31 \\
\hline 1 & $\mathrm{~S}$ & M & 3 & 100 & $57 / 13$ & $10 \mathrm{E} 17$ & 166E27 & $20 / 10$ & 6.7 & 0.63 & 79.8 & 22.2 & 20.8 \\
\hline 2 & $\mathrm{~S}$ & M & 3 & 63 & $215 / 10$ & $4 \mathrm{~W} 16$ & $18 \mathrm{E} 10$ & $36 / 2$ & 6.9 & 0.70 & 6.6 & 5.6 & 3 \\
\hline 3 & S & M & 3 & 84 & $27 / 15$ & $141 \mathrm{E} 16$ & $10 \mathrm{E} 20$ & $25 / 5$ & 4.6 & 0.53 & 21.6 & 21.6 & 11.8 \\
\hline 4 & $\mathrm{~S}$ & M & 2 & 79 & $215 / 5$ & $163 \mathrm{~W} 6$ & 0E0 & $25 / 0$ & 5.0 & 0.35 & 12.2 & 8.5 & 5.1 \\
\hline 5 & $\mathrm{~S}$ & M & 4 & 89 & $223 / 3$ & $37 \mathrm{~W} 23$ & 0E0 & $40 / 0$ & 8.2 & 0.45 & 14.7 & 5.4 & 4 \\
\hline 6 & $\mathrm{~S}$ & M & 2 & 42 & $252 / 12$ & 136W14 & 153NW12 & $58 / 10$ & 2.3 & 0.55 & 6.5 & 3.6 & 2.3 \\
\hline 7 & $\mathrm{~S}$ & M & 3 & 98 & $182 / 0$ & $180 \mathrm{E} 2$ & $67 N W 5$ & $55 / 2$ & 12.4 & 0.90 & 15.8 & 4.8 & 3.7 \\
\hline 8 & Opx & $\mathrm{P}$ & 2 & 236 & $54 / 14$ & 34E55 & 55NW18 & (68) & 5.0 & 0.00 & 8.5 & 2.8 & 2.1 \\
\hline 9 & $\mathrm{Hbl}$ & $\mathrm{P}$ & 4 & 113 & $243 / 34$ & 129SW37 & (115NE30) & $(57)$ & 6.1 & 0.15 & 19.8 & 10.6 & 7 \\
\hline 10 & $\mathrm{Hbl}$ & $\mathrm{P}$ & 4 & 127 & $56 / 13$ & $84 \mathrm{~N} 26$ & & $55 / 12$ & 5.2 & 0.18 & 63.2 & 5.2 & 5 \\
\hline 11 & $\mathrm{Hbl}$ & $\mathrm{P}$ & 3 & 119 & $55 / 21$ & $3 \mathrm{E} 29$ & $175 \mathrm{E} 15$ & $64 / 12$ & 6.6 & 0.30 & 10.3 & 7.8 & 4.5 \\
\hline 12 & $\mathrm{Hbl}$ & $\mathrm{S}$ & 3 & 129 & $59 / 22$ & $143 \mathrm{E} 22$ & $142 \mathrm{E} 36$ & $52 / 36$ & 4.3 & 0.17 & 29.2 & 8.8 & 6.9 \\
\hline 13 & $\mathrm{Bt}$ & $\mathrm{S}$ & 2 & 100 & $33 / 38$ & 164E46 & & & 3. & 0.15 & 13.2 & 10.1 & 5.8 \\
\hline 14 & $\mathrm{Bt}$ & M & 2 & 159 & $56 / 43$ & 174E47 & $170 \mathrm{E} 40$ & & 7.6 & 0.35 & 10.9 & 8.4 & 4.8 \\
\hline 15 & $\mathrm{Bt}$ & $\mathrm{P}$ & 3 & 172 & $83 / 15$ & $145 \mathrm{E} 17$ & & & 5.6 & 0.10 & 6.7 & 3.5 & 2.3 \\
\hline 16 & $\mathrm{Bt}$ & $\mathrm{P}$ & 5 & 51 & $60 / 7$ & $157 \mathrm{NE} 7$ & $164 \mathrm{E} 12$ & $063 / 12$ & 4.8 & -0.02 & 10 & 10 & 5 \\
\hline 17 & $\mathrm{Bt}$ & $\mathrm{S}$ & 4 & 106 & $244 / 26$ & 138SW27 & 0E0 & & 4.1 & -0.27 & 3 & 3 & 2 \\
\hline 18 & $\mathrm{Bt}$ & M & 4 & 121 & $247 / 27$ & 154SW27 & 159W21 & $234 / 21$ & 9.4 & 0.17 & 11 & 8 & 5 \\
\hline 19 & $\mathrm{Bt}$ & $\mathrm{P}$ & 6 & 68 & $252 / 0$ & $91 \mathrm{~N} 7$ & 0E0 & $70 / 00$ & 5.5 & 0.03 & 8.5 & 8.3 & 4.2 \\
\hline 20 & Hbll & M & 3 & 161 & $246 / 11$ & $156 \mathrm{~S} 11$ & 151SW16 & $242 / 16$ & 8.1 & 0.39 & 16.1 & 7.5 & 5.2 \\
\hline 21 & $\mathrm{Hbl}$ & $\mathrm{P}$ & 6 & 118 & $67 / 23$ & $5 \mathrm{E} 25$ & 154E21 & $69 / 21$ & 6.2 & 0.25 & 10.9 & 6.9 & 4.2 \\
\hline 22 & $\mathrm{Hbl}$ & M & 5 & 100 & $107 / 32$ & 174E35 & $161 \mathrm{E} 15$ & $073 / 15$ & 5.2 & 0.64 & 24.2 & 5.9 & 4.8 \\
\hline 23 & $\mathrm{Hbl}$ & $\mathrm{P}$ & 5 & 188 & $73 / 39$ & 144E40 & $164 \mathrm{E} 44$ & $74 / 44$ & 5 & 0.34 & 13.2 & 6.7 & 4.5 \\
\hline 24 & $\mathrm{Bt}$ & $\mathrm{S}$ & 6 & 77 & $53 / 15$ & $16 \mathrm{E} 24$ & $173 \mathrm{E} 18$ & $64 / 17$ & 4.1 & -0.06 & 13 & 13 & 7 \\
\hline 25 & $\mathrm{Hbl}$ & $\mathrm{P}$ & 6 & 133 & $71 / 16$ & $150 \mathrm{E} 16$ & $161 \mathrm{E} 17$ & $70 / 15$ & 7.2 & 0.30 & 6.8 & 3.9 & 2.5 \\
\hline 26 & $\mathrm{Hbl}$ & $\mathrm{P}$ & 4 & 119 & $83 / 6$ & $4 \mathrm{E} 7$ & 0E0 & $69 / 00$ & 4.8 & 0.41 & 14.6 & 6.4 & 4.5 \\
\hline 27 & $\mathrm{Hbl}$ & $\mathrm{C}$ & 9 & 108 & $153 / 57$ & $94 \mathrm{~S} 61$ & & & 1.7 & 0.41 & 37.3 & 17.7 & 12.6 \\
\hline 28 & $\mathrm{Hbl}$ & $\mathrm{P}$ & 6 & 114 & $80 / 27$ & 147E29 & $173 \mathrm{E} 26$ & $56 / 25$ & 3.3 & 0.22 & 57.2 & 45.1 & 31.4 \\
\hline
\end{tabular}




\begin{tabular}{|l|l|l|l|l|l|l|l|l|l|l|l|l|l|}
\hline Site & Rt & Mi & $\boldsymbol{n}$ & Km & K1 & Mf & Ff & Fl & Pp\% & T & E12 & E23 & E31 \\
\hline 29 & Opx & S & 6 & 282 & $19 / 80$ & $165 E 84$ & $165 E 65$ & & 3.1 & 0.25 & 15.2 & 9.5 & 5.9 \\
\hline 30 & Bt & P & 5 & 119 & $61 / 17$ & $153 \mathrm{E} 17$ & & & 5.9 & 0.54 & 21.5 & 6.8 & 5.2 \\
\hline 31 & Opx & S & 5 & 193 & $57 / 31$ & $147 \mathrm{E} 31$ & & & 4 & 0.24 & 16.9 & 10.8 & 6.7 \\
\hline 32 & Opx & S & 6 & 200 & $51 / 12$ & $126 E 13$ & & & 2.7 & -0.23 & 11.4 & 11.4 & 7.1 \\
\hline 33 & Bt & P & 4 & 56 & $231 / 6$ & $31 \mathrm{~N} 18$ & & & 6.5 & 0.39 & 13.5 & 6.3 & 4.3 \\
\hline 34 & Hbl & C & 4 & 113 & $265 / 29$ & $15 N 30$ & & & 0.6 & 0.55 & 50 & 19 & 15 \\
\hline 35 & Opx & S & 5 & 214 & $62 / 25$ & $172 \mathrm{E} 26$ & & & 3.6 & 0.03 & 7 & 7 & 3 \\
\hline 36 & Opx & S & 3 & 224 & $196 / 6$ & 179 W19 & & & 3.1 & 0.39 & 41 & 21 & 15 \\
\hline
\end{tabular}

Rock types: S: Syenogranite, Bt: Bt monzogranite, Hbl: Hbl + t monzogranite, Opx: Opx granodiorite Microstructures: S: subsolidus, P: protomylonite, M: mylonite, C: cataclase. Orientation of the linear structures corresponds to trend and plunge.

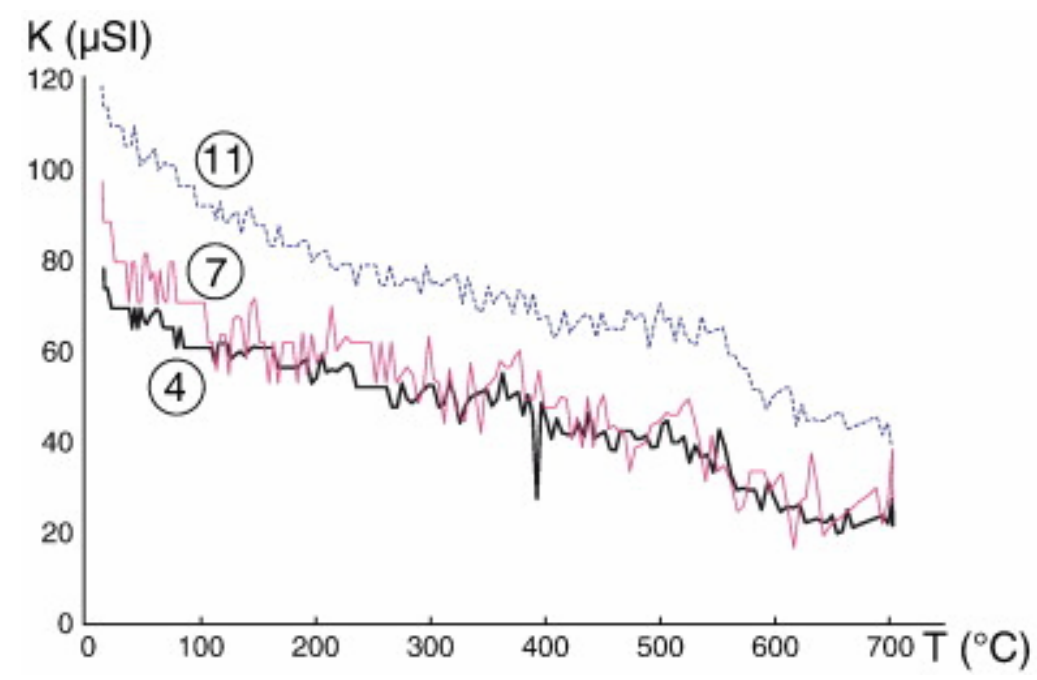

Fig. 2. : $K$ vs $T$ measurements of three samples of the Mykonos laccolith. 

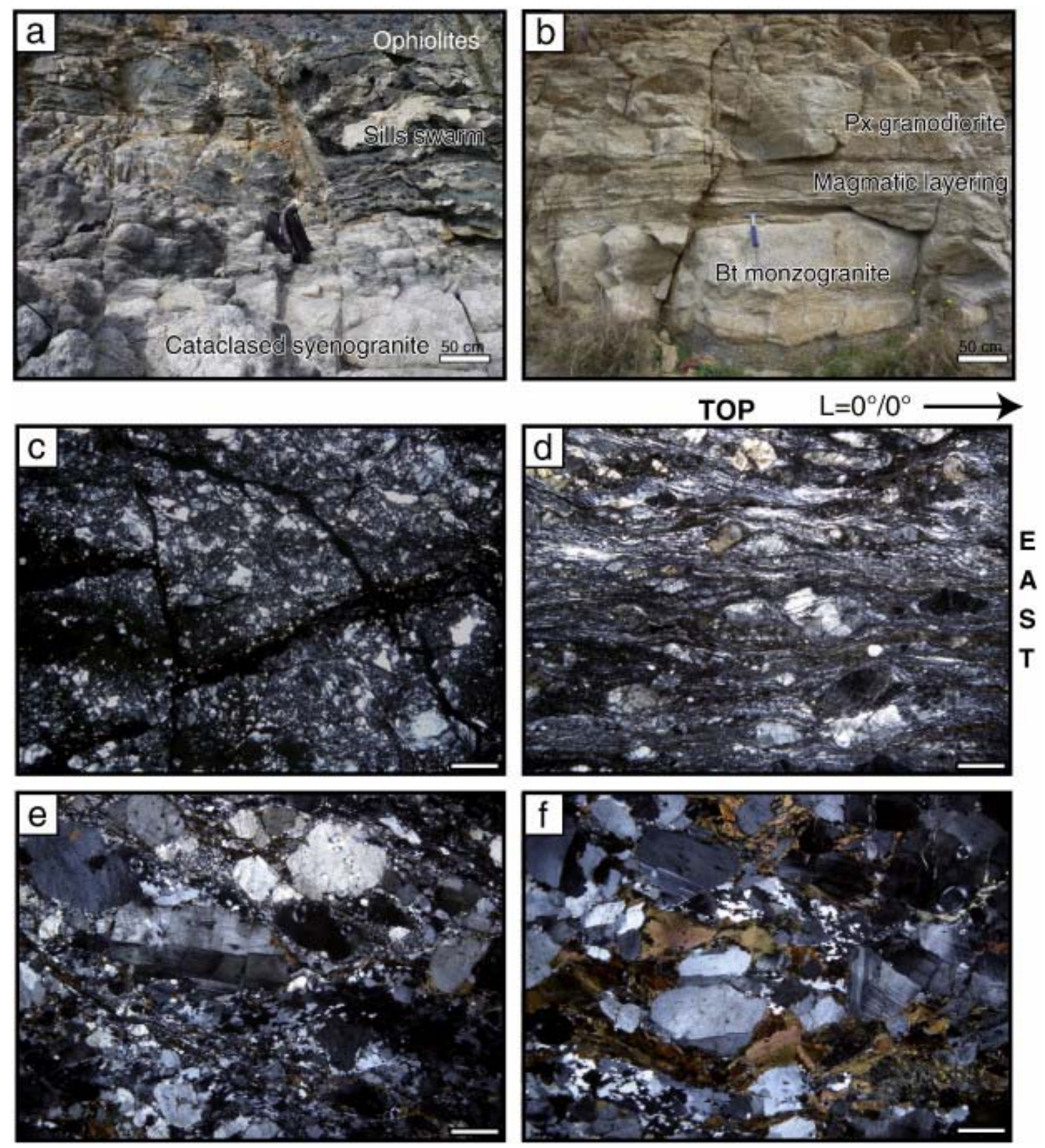

Fig. 3. : Photographs of various rocks observed in the Mykonos laccolith, scale bar of microphotographs $=1 \mathrm{~mm}$ : (a) field photograph of the upper intrusive contact of the Mykonos laccolith (close to site 2), (b) field photograph showing relationships between the biotite monzogranite and the pyroxene granodiorite (site 20), (c) microphotograph of a cataclasis in hornblende monzogranite (site 34), (d) microphotograph of a low temperature ultramylonite (site 7), (e) microphotograph of a high to middle temperature protomylonite (site 9), (f) microphotograph of a subsolidus microstructure (site 12). 


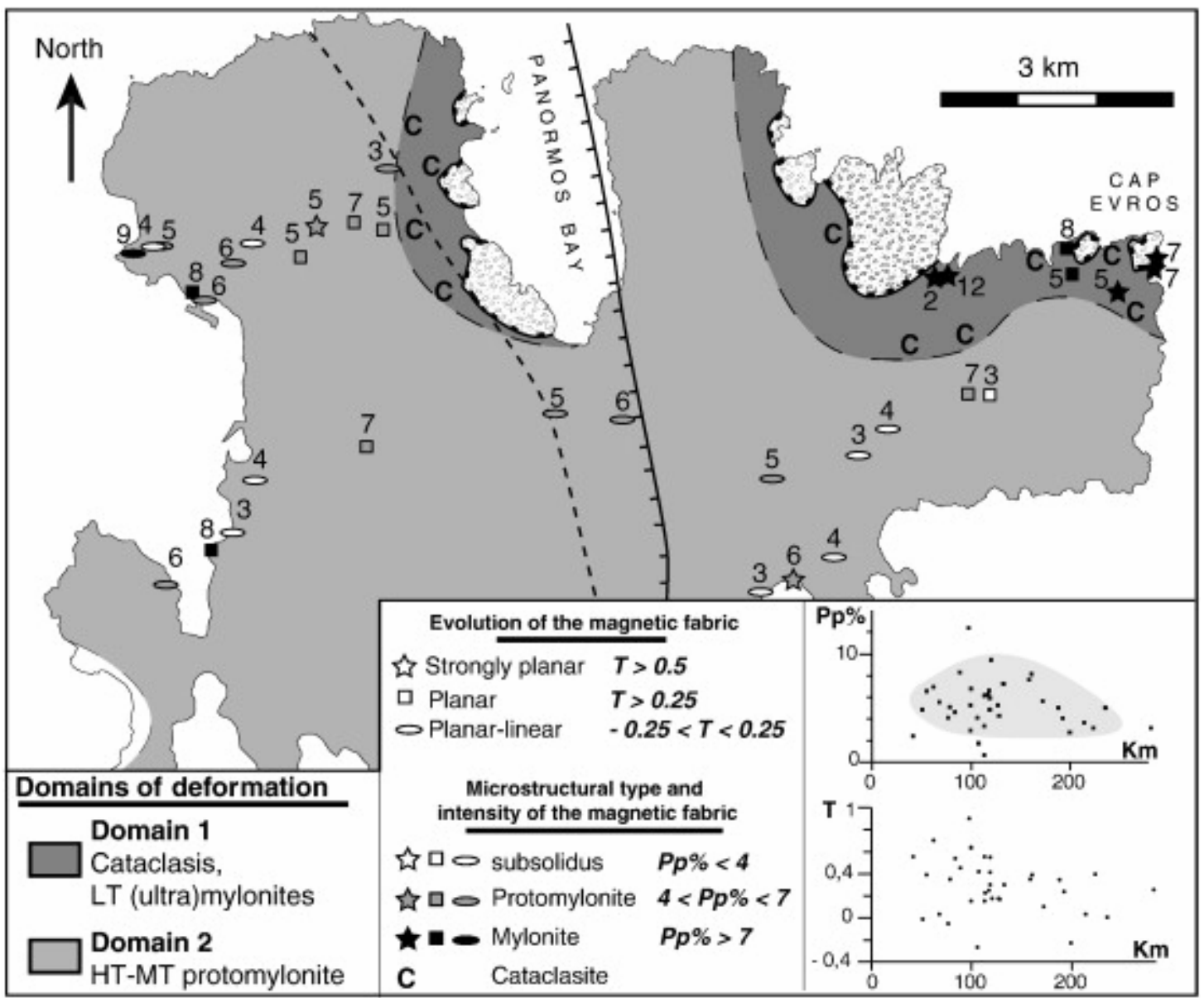

Fig. 4. : Characterization of the deformation in the Mykonos laccolith by means of microstructural and magnetic data such as the Total Anisotropy parameter ( $P p \%)$ and the Shape parameter $(T)$. Numbers on the map correspond to the values of $\mathrm{Pp} \%$ for each site. 

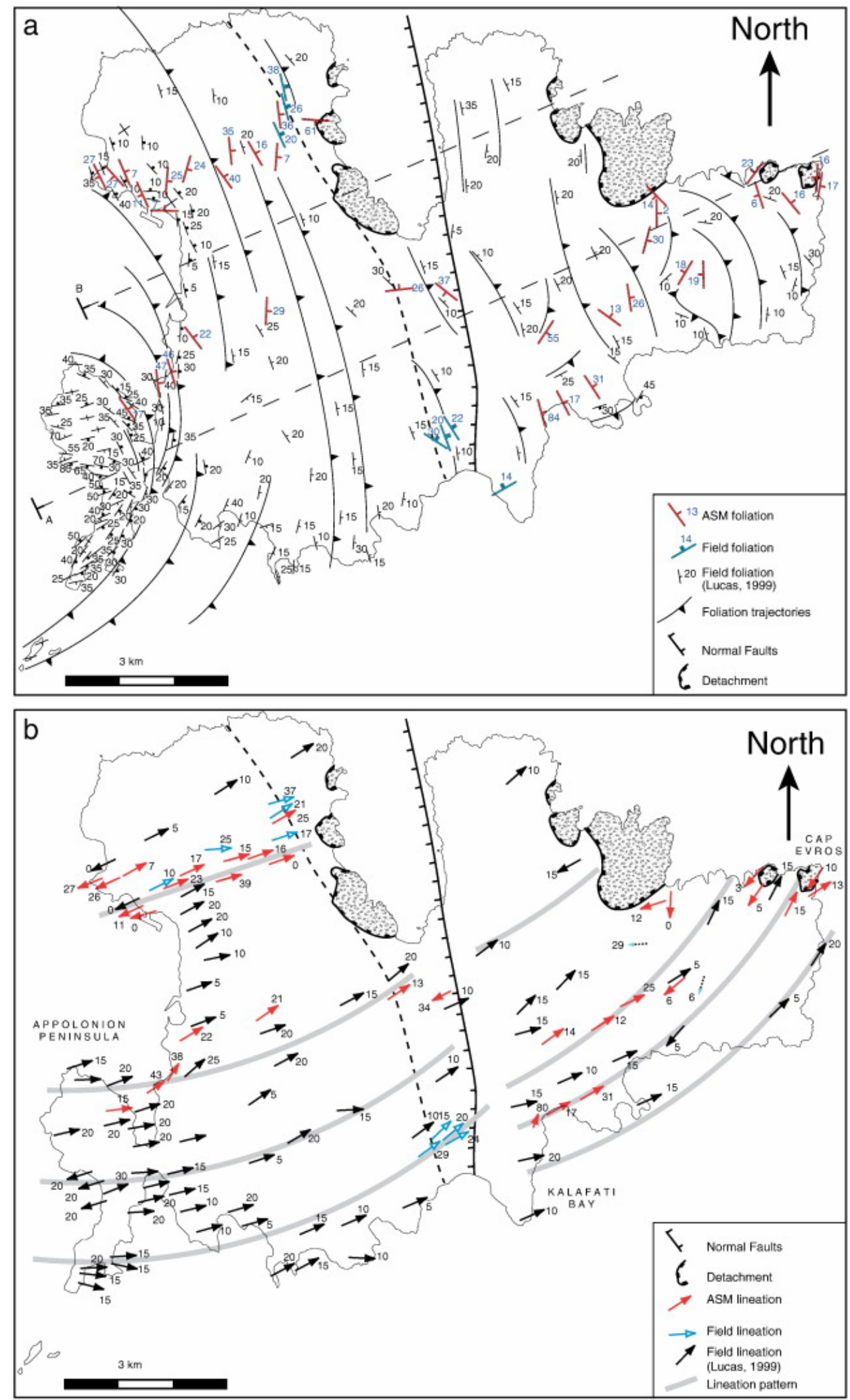

Fig. 5. : Structural features of the Mykonos laccolith. a) Foliations and foliation trajectories. $\mathrm{A}$ and $\mathrm{B}$ correspond to the location of the cross-sections of Fig. 6. (b) Lineations and lineation pattern. 


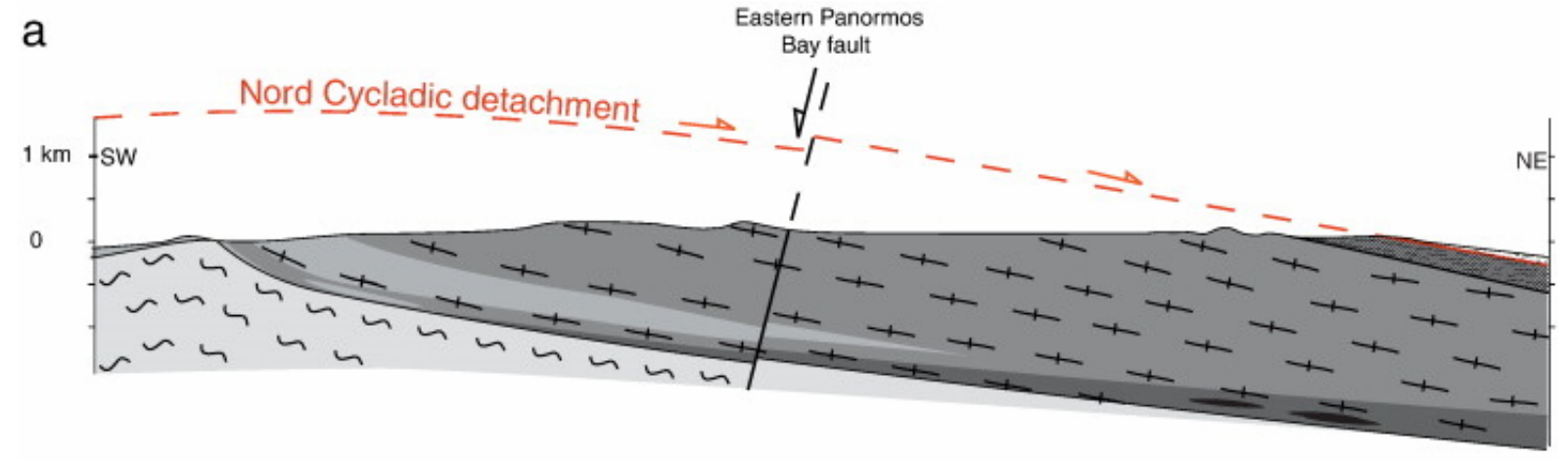

b

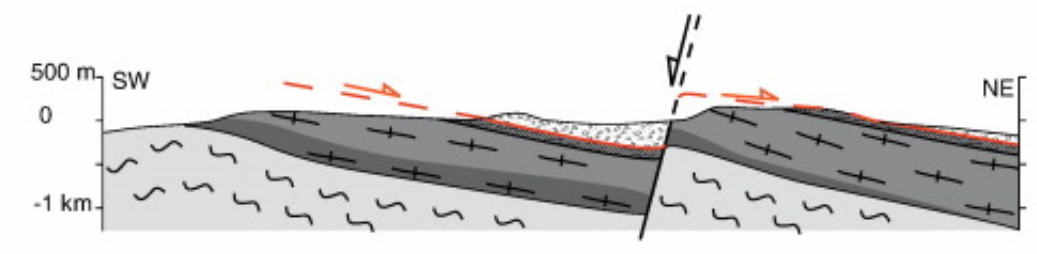

Upper Cycladic Unit and Late Miocene $\square$ Ultramylonitic and cataclastic granites $\square$ Bt + Hbl \pm Opx granodiorite with mafic bodies
to Pliocene sediments
$\square$ Bt + Hbl monzogranite

Fig. 6. : Cross-sections of the studied area located on Fig. 5a. 


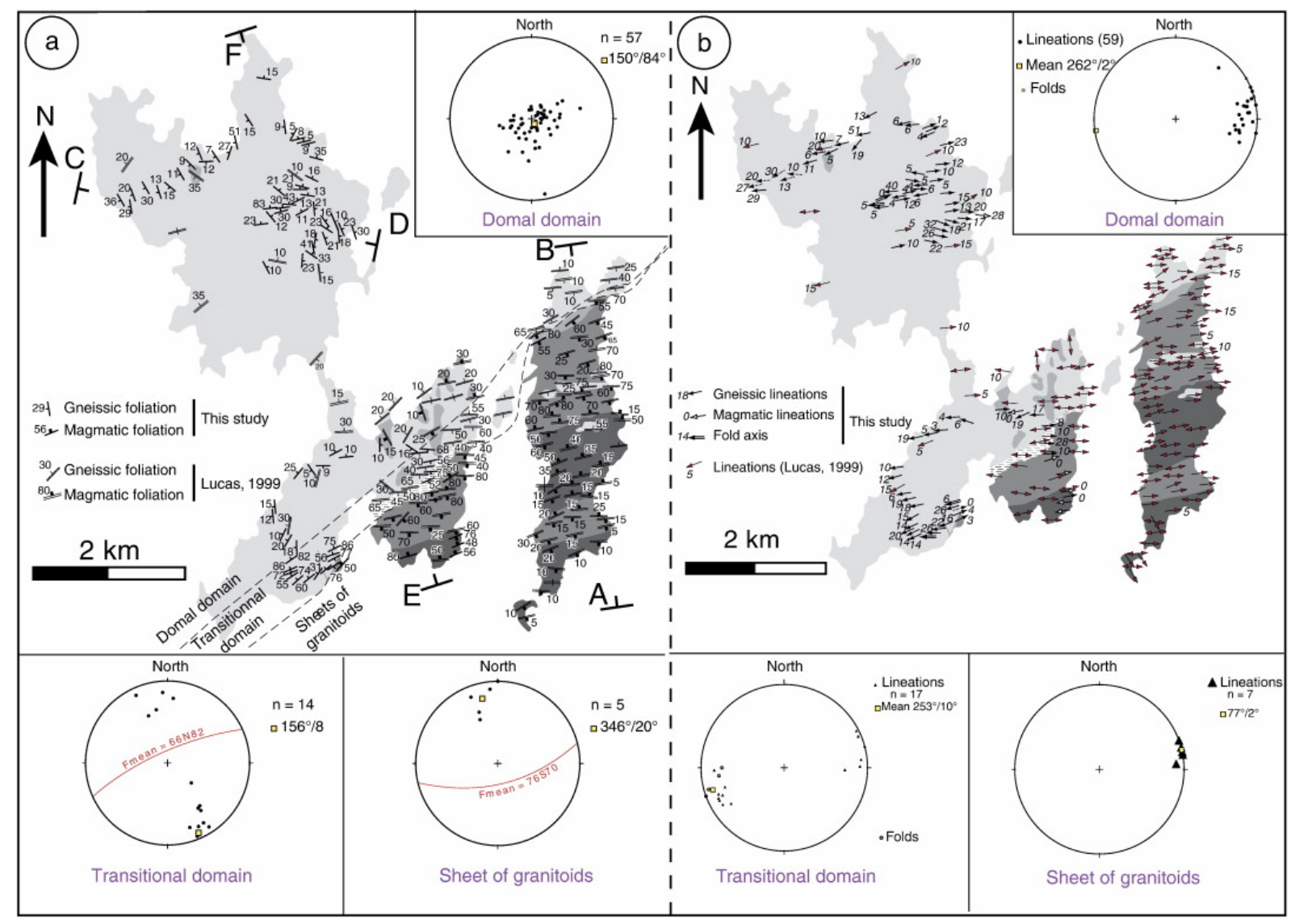

Fig. 7. : Structural features of the Rhenia and Delos island. (a) Foliation map and location of cross-sections and stereodiagrams of foliation poles for the different domains (Schmidt's lower hemisphere equal area projection), $\mathrm{AB}, \mathrm{CD}$ and $\mathrm{EF}$ correspond to the location of the cross-sections of Fig. 8. (b) Lineation map and stereograms.

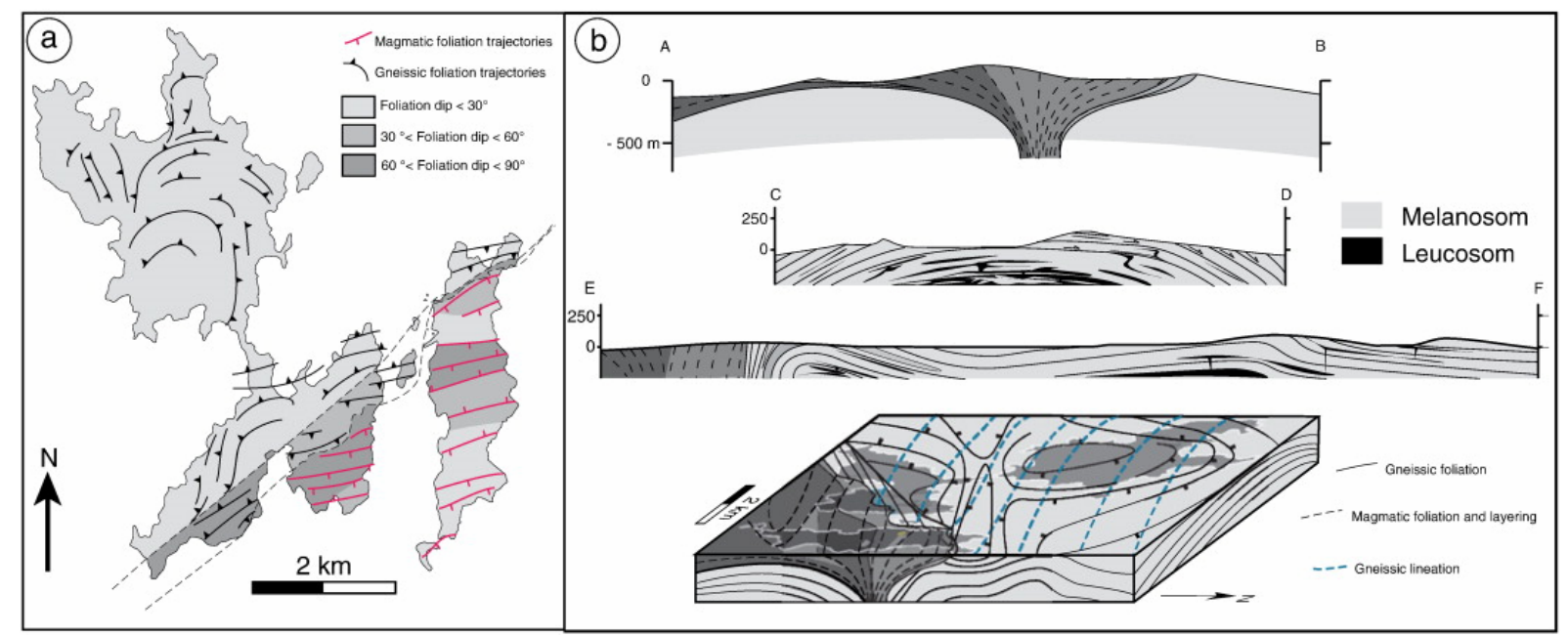

Fig. 8. : (a) Foliation trajectories and dipping domains map of the Rhenia and Delos island. (b) Cross-sections of the studied area located on [Fig. 7] and [Fig. 3]d interpretative representation of the structural features of the Rhenia and Delos island. 

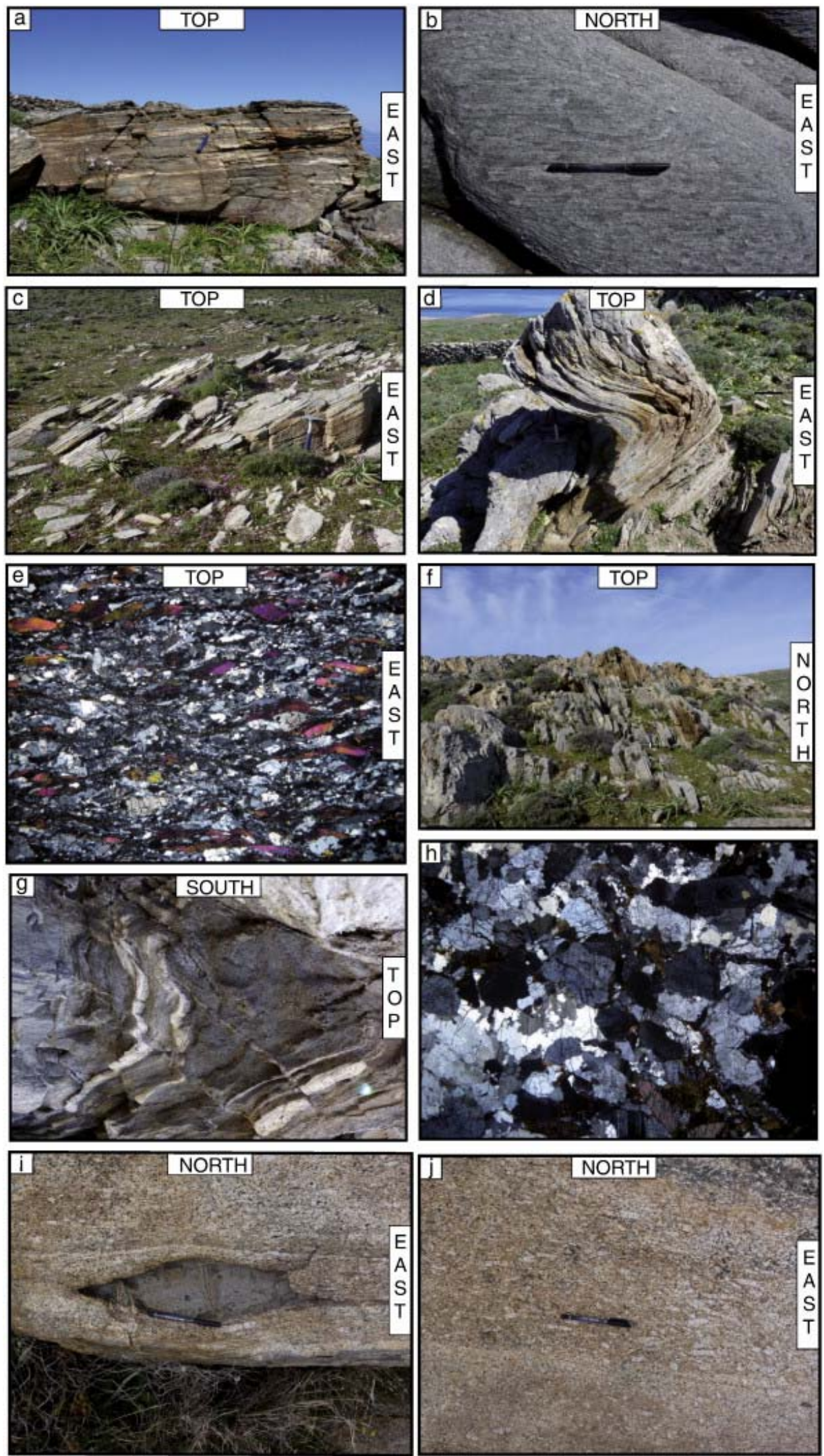

Fig. 9. : Photographs and microphotographs of various rocks observed in the Rhenia and Delos island, see explanation in the text, scale bar of microphotographs $=1 \mathrm{~mm}$. 


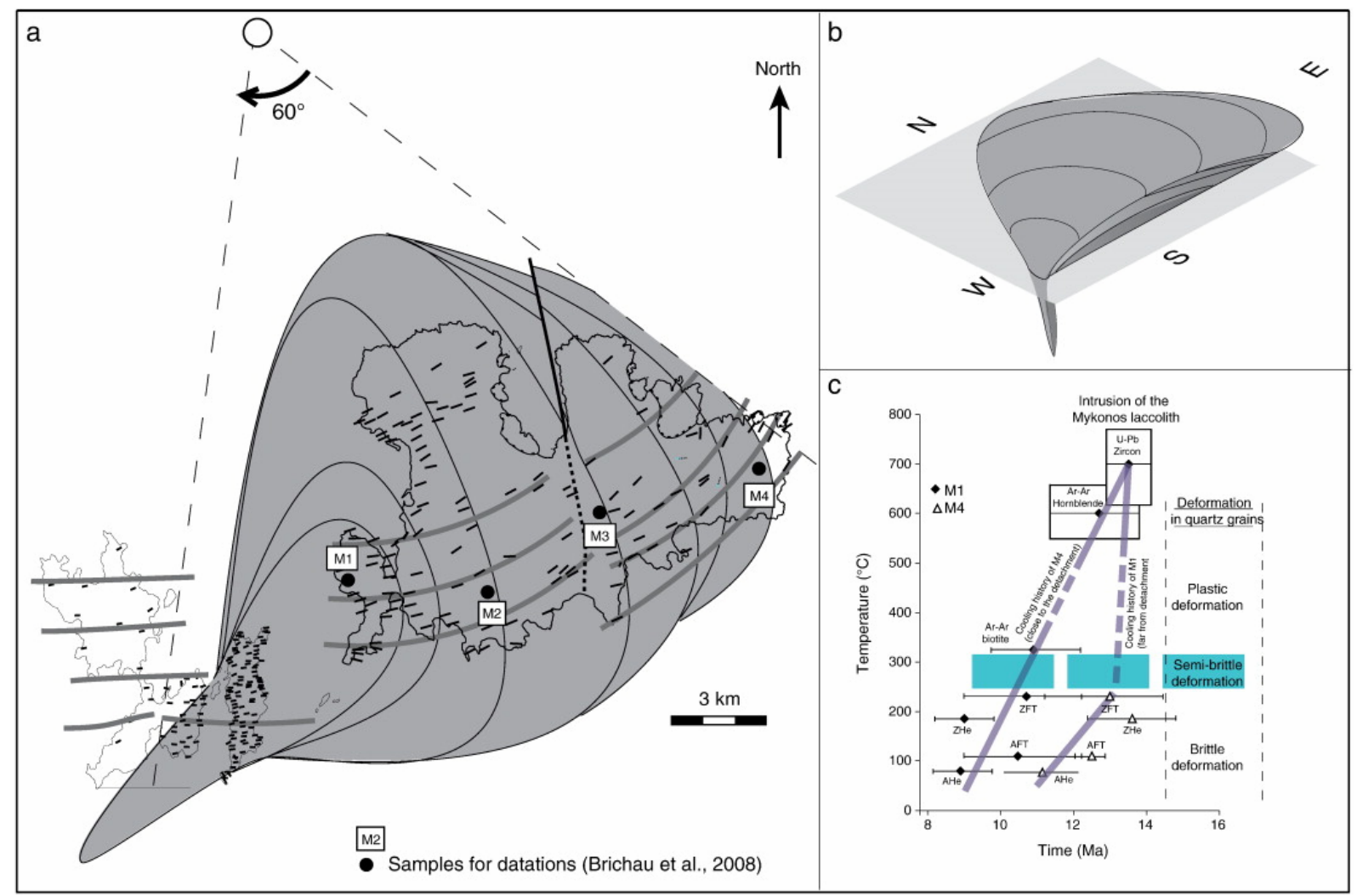

Fig. 10. : Interpretative sketches. (a) Study in map view of the rotation around a vertical axis of the stretching lineations of the Mykonos laccolith. (b) 3D interpretative representation of the laccolith. (c) $T-t$ history for the eastern and western side of the Mykonos pluton. All the thermochronologic data are from Brichau et al. (2008). Closure temperature for the different isotopic systems are as follows: $\mathrm{U}-\mathrm{Pb}\left(1000{ }^{\circ} \mathrm{C}\right.$, Cherniak and Watson, 2000), $\mathrm{Ar}-\mathrm{Ar}$ on Hornblende (560-650 ${ }^{\circ} \mathrm{C}$, [Dahl, 1996a], [Harrison, 1981] and [Villa et al., 1996]), Ar-Ar on biotite (300-350 ${ }^{\circ} \mathrm{C}$, [Dahl, 1996b] and [Harrison et al., 1985]), ZFT (250-220 ${ }^{\circ} \mathrm{C}$, [Brandon and Vance, 1992] and [Brandon et al., 1998]), ZHe (200-170 ${ }^{\circ} \mathrm{C}$, Reiners et al., 2004), AFT (110-60 ${ }^{\circ} \mathrm{C}$, e.g. [Donelick, 1991] and [Green et al., 1989]), AHe (80-65 ${ }^{\circ} \mathrm{C}$, e.g. Wolf et al., 1996). Distinct behavior of quartz with temperature evolution are from Stöckhert et al. (1999). 


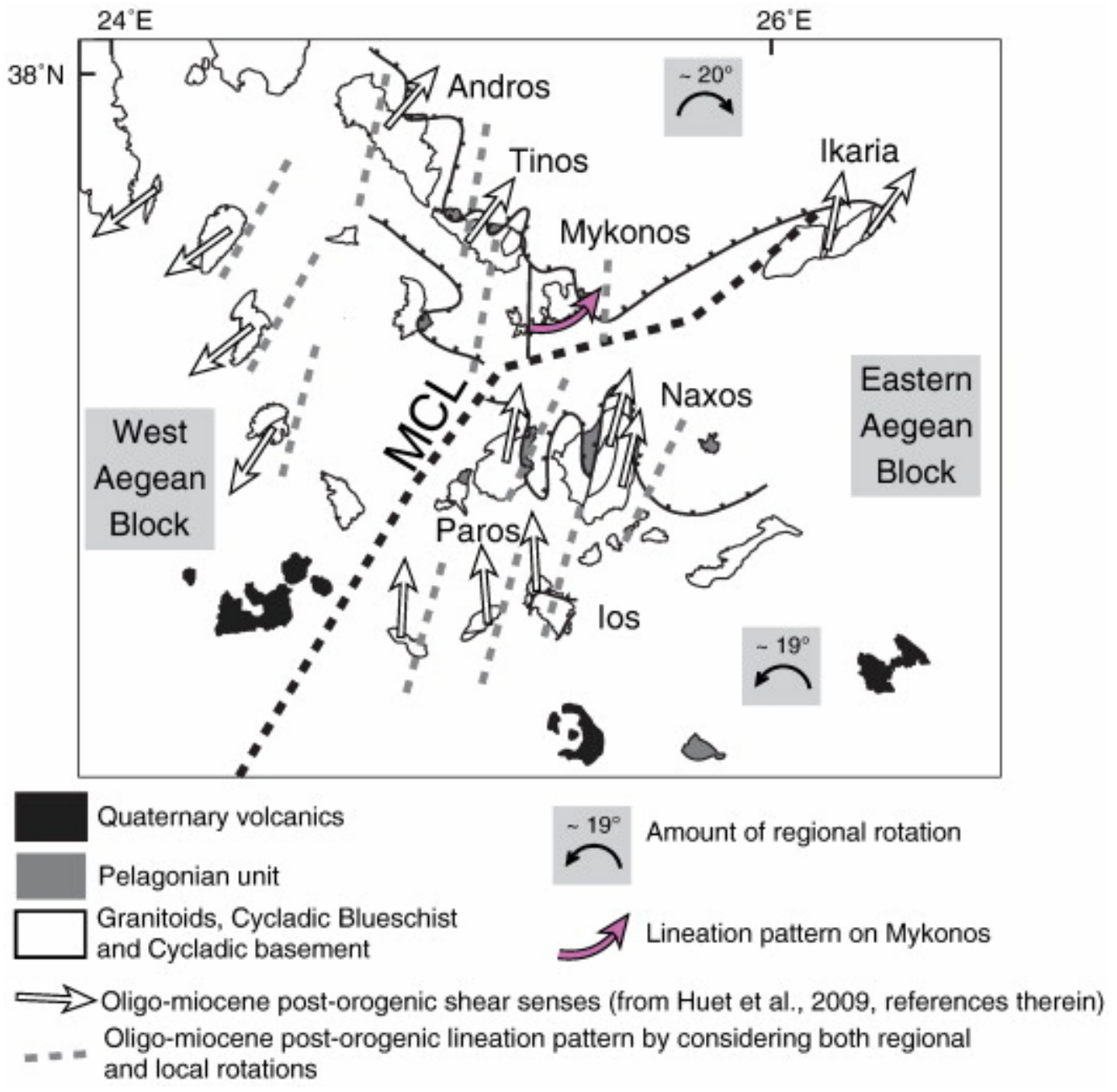

Fig. 11. : Structural map of the Cyclades representing the pattern of lineations on the various islands. $\mathrm{MCL}=$ Mid-Cycladic lineament. 

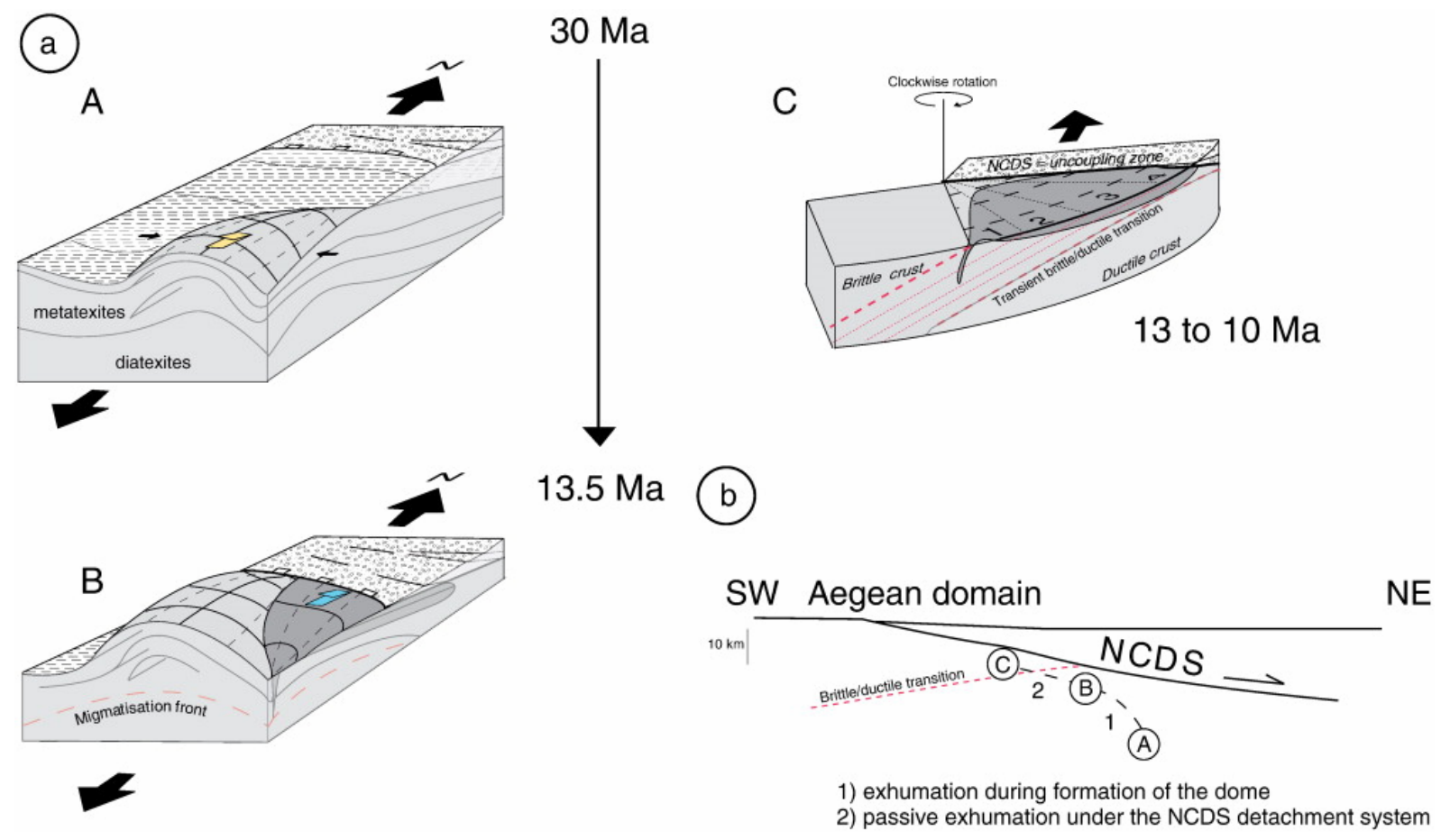

Fig. 12. : (a) Interpretative sketches showing the various stages of the development of the Mykonos MCC: A: coeval partial melting of the lower cycladic crust, top to the north-directed flow of the ductile crust and formation of a gneissic dome in a constrictive strain regime, B: emplacement of the Mykonos laccolith at the top the Cycladic basement during its cooling history, C: Progressive rotation of the successively exhumed zone of the Mykonos laccolith. (b) Schematic NE-SW cross-section of the Aegean domain showing the interpretative path of the top of the Rhenia dome during exhumation. 